University of Michigan Law School

University of Michigan Law School Scholarship Repository

Articles

Faculty Scholarship

1997

International Taxation of Electronic Commerce

Reuven S. Avi-Yonah

Available at: https://repository.law.umich.edu/articles/2328

Follow this and additional works at: https://repository.law.umich.edu/articles

Part of the Science and Technology Law Commons, Taxation-Transnational Commons, and the Tax Law Commons 


\title{
International Taxation of Electronic Commerce
}

\author{
REUVEN S. AVI-YONAH;
}

I. Introduction ............................... 507

II. What Is New About Electronic Commerce? .......... 510

III. Two Principles of International Taxation............ 517

A. Defining the Tax Base: The Single Tax Principle ... 517

B. Dividing the Tax Base: The Benefits Principle ..... 520

IV. The Treasury White Paper: A Residence-Based

Regime .................................... 523

V. Three Proposals Toward a Solution ................ 531

A. Impermanent Establishments ................. 532

B. Royalties, Services, and Sales ................ 541

C. Transfer Pricing............................ 545

VI. Conclusion: A Comparative Perspective............ 550

A. Electronic Commerce and U.S. State Income

Taxes .................................... 551

B. Electronic Commerce and U.S. State Retail Sales Taxes ................................... 552

C. Electronic Commerce and the VAT............. 554

D. The Impact of Electronic Commerce: Substitution or Borrowing? ............................... 555

\section{INTRODUCTION}

May 19, 2001: On this bright and sunny spring day, Linda Jones wakes up in her Boston townhouse and decides that this, finally, is the day she is going to get her new dream kitchen. No more browsing in boring furniture stores or leafing through old-fashioned mail order

\footnotetext{
* Assistant Professor of Law, Harvard Law School. I would like to thank the participants in the 1997 Tax Law Review Symposium on Taxation and Electronic Commerce (especially my commentators, Stanley Katz and Stef vanWeeghel), the participants in the 1997 Harvard Seminar on Current Research in Taxation (especially my comentator, Hugh Ault), and Bill Andrews, Howell Jackson, Larry Lessig, Oliver Oldman, Michael Schler, Philip West, and Bernie Wolfman for their extremely helpful comments on earlier versions of this Article. Special thanks are due to my research assistant Sam Mantilla for his tireless efforts in preparing the article for publication, and to Avia and Amos Sheffer for enabling me to have the time to write it. This article could not have been written without the love and support of Orli, Michael and Shera Avi-Yonah.
} 
catalogues! No, she is going to do this differently, as befits the new millennium: Linda is going to order her kitchen on the Web. A few quick clicks of the mouse, and Linda finds what she is looking for: kitchens.com, an all-encompassing kitchen design and sales Web site owned by KitchenCo, a multinational whose parent company is incorporated and managed in Guyana. Linda quickly enters into an electronic conversation with the company's marketing representative in Guyana. She answers his questions and e-mails him a copy of her kitchen's measurements. He, in turn, conveys her wishes to a designer, who works from his beachfront condo in Bermuda. The designer is able to fulfill Linda's specifications by accessing a mainframe computer in Buenos Aires. A company employee residing in Sydney, Australia, where the company had no other business, wrote the design software on the computer specifically for this purpose.

The Buenos Aires computer is able to do some of the design work itself: It can check Linda's measurements, compare them to available materials and appliances, make up a list of possibilities within Linda's budget, and check each possibility for safety and durability. The designer in Bermuda can use the options he downloaded from the computer, as well as a database of design options from the same source, to come up with Linda's dream kitchen. After obtaining Linda's electronic approval, the work order then is forwarded to skilled artisans working in the Italian countryside, who serve as consultants while the actual construction of the kitchen itself is performed at the company's factory on the Penang Peninsula of Malaysia, with the appliances supplied from Germany. Finally, after Linda pays for the order by using her e-money account on the Web, the finished kitchen is shipped to her from Malaysia for installation in Boston. For the installation, Linda also receives a copy of the design software, so that she can make last minute changes in case any of the features did not match her vision as they were actually installed. ${ }^{1}$

Linda's dream kitchen is the tax administrator's nightmare. Consider the taxing jurisdictions that potentially could impose an income tax on KitchenCo's income from Linda: Guyana (KitchenCo's country of legal residence and the location of its sales force); the United States (Linda's country of residence and where consumption of the goods takes place); Bermuda (where the designer works); Argentina (location of the mainframe that stores the order and participates in the design); Australia (where the software that made the design possible was written); Italy (location of the consultants); Germany (production site for the appliances); and Malaysia (production site for the

1 This example is based on a similar one found in Frances M. Horner \& Jeffrey Owens, Tax and the Web: New Technology, Old Problems, 50 Bull. Int'l Fisc. Doc. 516, 516 (1996). 
kitchen). Which of these jurisdictions should have the right to tax KitchenCo's income? If more than one jurisdiction has this right, how can the income be allocated among them to prevent either multiple taxation or nontaxation? What kind of income does KitchenCo have, and how does the answer to this question relate to the previous ones?

This Article suggests some possible answers to these questions, and attempts to address the ways in which the rise of electronic commerce poses a challenge to traditional concepts of international taxation of active business income. Section II describes in general terms the current and likely future development of electronic commerce over the "information superhighway," including both the Internet and corporate "intranets." It focuses in particular on the ways in which electronic commerce is different from the traditional mail-order business that are significant from a tax perspective.

Section III establishes a normative framework for the analysis by defining two principles that underlie the international tax regime (the Single Tax Principle and the Benefits Principle), both of which are undermined by the rise of electronic commerce. The Single Tax Principle states that income from cross-border transactions should be subject to tax once (not more and not less), at the rate determined under the Benefits Principle. The Benefits Principle assigns the right to tax active (business) income primarily to the source jurisdiction, while the right to tax passive (investment) income is assigned primarily to the residence jurisdiction. In each case, however, other jurisdictions retain a residual right to tax for cross-border income that is not taxed by the jurisdiction that has the primary right to tax it.

Section IV addresses Treasury's discussion paper on global electronic commerce, ${ }^{2}$ and in particular its suggestion that electronic commerce should be taxed primarily on a residence basis. Section IV argues that this suggestion is incompatible with both the Single Tax and Benefits Principles underlying the current international tax regime, and is unlikely to be successful in practice.

Section V is the core of the Article, and includes my three proposals for changing the current international tax rules to address the specific problems raised by electronic commerce. These proposals can be applied unilaterally (that is, they do not require coordinated actions, although they would require carving electronic commerce out of bilateral tax treaties). Initially, the three proposals are intended to apply only to electronic commerce, although it may be possible over time to expand their scope to other types of commerce as well.

2 Office of Tax Policy, Treasury Dep't, Selected Tax Policy Implications of Global Electronic Commerce (1996), reprinted in Daily Tax Rep. (BNA), Nov. 22, 1996, at L-1 [hereinafter Treasury White Paper]. 
The first proposal is to change the concept of "permanent establishment," which is the threshold that is required to allow a taxing jurisdiction to tax active income on a source basis. Currently, this threshold emphasizes physical presence within a taxing jurisdiction. Because electronic commerce can be carried out without such a physical presence, I propose to use as the threshold for electronic commerce a de minimis amount of gross income earned within the taxing jurisdiction. Once over the threshold, income from electronic commerce initially should be taxed (by means of a withholding tax) by the jurisdiction in which goods and services are consumed (the "Demand Jurisdiction"). In accordance with the Benefits Principle, however, the tax base then would be shared with jurisdictions in which goods and services are produced if they impose a level of tax comparable to that of the Demand Jurisdiction.

The second proposal addresses the distinction among income from services, royalties, and sale of goods, each of which is currently taxed in a different manner. Since electronic commerce renders this distinction largely incoherent, I propose that for electronic commerce, royalties, income from services, and income from sales all be treated as active business income, without further distinctions. Such active business income as a whole then would be subject to the de minimis threshold and the withholding tax outlined in the previous proposal.

The third proposal is based on the observation that electronic commerce makes it extremely difficult to enforce transactionally based transfer pricing (as envisaged by the OECD guidelines on this topic). Therefore, I propose to address transfer pricing in the electronic commerce context by using global profit splits on the basis of a functional analysis of the related parties involved, with any residual profit allocated to the Demand Jurisdiction.

Section VI concludes by comparing the problems posed by electronic commerce to the international income tax regime with the problems it raises in three other contexts: the U.S. state income and retail sales taxes and the value added tax. Some of these latter taxes seem better suited to deal with electronic commerce than the international tax regime. The conclusion argues that the solution is not to substitute, for example, the VAT for the income tax, but rather to borrow some of the methods used by these other taxes and incorporate them into the international tax regime, in the ways suggested by Section $\mathrm{V}$.

\section{What Is New About Electronic Commerce?}

"Electronic commerce" has been defined as "the ability to perform transactions involving the exchange of goods or services between two 
or more parties using electronic tools and techniques." 3 The essential prerequisite for the existence of electronic commerce is thus the ability of the parties to communicate with each other by electronic means. This ability has existed since the rise of the telegraph in the 1830's, and has grown exponentially since the arrival of the telephone in the 1890 's. Thus, as is well known to anyone who has ordered anything over the telephone, electronic commerce (as distinguished from commerce based on computer networks) is not new. It is, therefore, important to begin with the question, what, if anything, has changed in the way electronic commerce is conducted in the 1990's, so as to present new challenges to the international tax regime?

There are three elements in the Linda Jones example that distinguish it from a traditional mail order sale, in which Linda receives a catalog in the mail, orders items by telephone, and pays for them with her credit card. These new elements are interactivity, speed, and electronic payment. ${ }^{4}$ First, Linda's transaction is interactive: Rather than being confined to the choices presented to her in a paper catalog, she was able to engage in an online conversation with a KitchenCo representative who could offer her a range of goods and services modified precisely to suit her needs and budget. Moreover, Linda could further modify her order as the process went along, going over the design plans at each stage with the on-line consultants, and even download the software necessary to modify the design at the installation phase. Before the 1990's, this kind of mixture of goods and services would be available to Linda only by having KitchenCo representatives visit her in person. Moreover, it is striking that Linda can consume services over the Internet that previously required the physical presence of the service provider. ${ }^{5}$ This disjunction between the provision and consumption of services is a key to the tax problem posed by electronic commerce.

Second, the ability to order the kitchen over the Internet significantly speeds up the production process. The speed of electronic communication via the computer is also essential for KitchenCo's ability to disperse its workforce over the globe. Only the actual shipping of the kitchen components still slows up the process, but this constraint only applies when the goods being sold cannot themselves be "digi-

3 Id. \$3.2.1, at 7 .

${ }^{4}$ Horner \& Owens, note 1, at 516-17; see also Charles McLure, Jr., Taxation of Electronic Commerce: Economic Objectives, Technological Constraints, and Tax Law, 52 Tax L. Rev. 269 (1997) [hereinafter Electronic Commerce]; Bruce J. Reid, Nexus and Electronic Commerce 8 (Harvard Law School Symposium on Multi-jurisdictional Taxation of Electronic Commerce, Apr. 1997).

5 See Interactive Servs. Ass'n Task Force, White Paper. Logging On to Cyberspace Tax Policy, 12 St. Tax Notes 209, 219 (Jan. 20, 1997) [hereinafter ISA White Paper]. 
tized" (that is, converted into a computer-readable and Internet-transferable form) ${ }^{6}$

The third change is electronic payment. While still in its infancy, it appears likely that it will be possible to pay for products directly and securely over the Web by using various forms of e-money (such as "smart cards" loaded with currency equivalents from an electronic bank). ${ }^{7}$ This feature speeds up the transaction and reduces credit risk. It also makes it possible to charge over the Internet for very small amounts that aggregate to significant sums, such as $1 / 100$ of a cent for each byte downloaded from a Web site. ${ }^{8}$

What makes these features possible in the Linda Jones case is the Internet, which in turn is only a part of the "information superhighway." A lot has been written about the information superhighway, and only a few of its features that are relevant to the taxation of electronic commerce need to be summarized here. The information superhighway, or "global information infrastructure," is a convergence of several separate communications and computer systems into a single, interoperable network of networks. 9 The best known of these networks is the Internet, which began in 1969 as a U.S. Department of Defense project designed to be safe from a nuclear attack. ${ }^{10}$ Because of this need, the Internet was conceived from the beginning as lacking a single "nerve center" or a defined hierarchical structure. ${ }^{11}$ Instead, the Internet currently can be defined as

[A] world-wide network of networks with gateways linking organizations in North and South America, Europe, the Pacific Basin and other countries. ... The organizations are administratively independent from one another. There is no central, worldwide, technical control point. Yet, working together, these organizations have created what to a user seems to be a virtual network that spans the globe. ${ }^{12}$

6 Treasury White Paper, note $2, \S 2.2$, at 5; see also Susan M. Lyons, International Sessions Key on Check-the-Box, Software, Cybertax, 74 Tax Notes 277, 280 (Jan. 20, 1997).

7 See Treasury White Paper, note 2, §5.7-5.8, at 15-16; see also U.S. Treasury Dep't, Exploring the World of Cyberpayments 8-12 (1995).

8 See Arthur J. Cordell, T. Ran Ide, Luc Soete \& Karin Kamp, The New Wealth of Nations: Taxing Cyberspace 54-55 (1997); Howard E. Abrams \& Richard L. Doernberg, How Electronic Commerce Works, 14 Tax Notes Int'l 1573, 1585 (May 12, 1997); Luc Soete \& Karin Kamp, Taxing Consumption in the Electronic Age (Harvard Law School Symposium on Multi-Jurisdictional Taxation), reprinted in Intermedia, Aug. 1997, at 20-21.

9 Treasury White Paper, note 2, §2.1, at 5 .

10 Id.; Jack Rickard, Editors Notes: Ring That Bell. . , Boardwatch, June 1995, at 8.

11 Treasury White Paper, note 2, at 145.

12 Treasury White Paper, note 2, § 2.4, at 5-6. 
What links the Internet together and enables its computers to communicate regardless of differences in hardware or software is the Transmission Control Protocol/Internet Protocol (TCP/IP), which is a means of specifying how data is broken up in "packets" and assigned addresses to be transferred over the Internet. ${ }^{13}$ The packets are sent over "routers," which are hundreds of thousands of computers, which are used to transmit data over the Internet. ${ }^{14}$ Each router does not need to be connected to every other one. The packets are sent in a general direction and are transmitted onward, using the best available route (taking into account traffic congestion) until they arrive at their destination. ${ }^{15}$ A single message can be broken up into thousands of packets, each taking a different route from origin to destination. ${ }^{16}$ The packets generally are sent over existing telephone networks, which, since the introduction of fiber optic cables have virtually limitless capacity. ${ }^{17}$ They also could be routed over satellite links or cable TV systems. ${ }^{18}$ As for the data, anything that can be digitized (which includes text, sound, images, video, and other content) can be sent over the Internet. ${ }^{19}$

The information superhighway also includes several thousand "Intranets," which are corporate networks similar to the Internet but confined to users within a single corporation. ${ }^{20}$ Because they are internal, intranets offer added security (even with current encryption technologies, sending data over the public Internet is potentially insecure), and increased connection speeds, since multinationals can afford direct links that are much faster than those available to the average consumer with a modem. ${ }^{21}$ In the KitchenCo example, the transfers of data from the various KitchenCo centers (the Bermuda designer, the Argentinean mainframe, the Australian programmer, the Italian consultants, and the Malaysian factory) could take place over KitchenCo's intranet, leaving only the contact with Linda to be performed through KitchenCo's Web site on the Internet.

13 Id. at 6; see also Abrams \& Doernberg, note 8, at 1584-85; Henry H. Perritt, Jr., What Is the Internet? (Sept. 11, 1995) <http://www.cilp.org/vcilp/technotes/what is5.htm>; Rickard, note 10 , at 8 .

14 Abrams \& Doernberg, note 8, at 1585 n.41 ("Routers and switches are really special purpose computers that send each packet of information on its way to its intended destination.").

15 Id. at 1585 \& $\mathrm{n} .41$.

16 Id. at 1584-85.

17 See Treasury White Paper, note 2, $\$$ 2.2, 3.2.7, at 5, 9 .

18 Id. $\S \S 2.1,2.2$, at 5 .

19 Id. $\S 2.2$, at 5 .

20 Id. $\$ 2.3$, at 5 .

21 See id. 
Electronic commerce over the Internet currently includes a wide variety of offerings. It is possible to buy tangible goods (for example, books: amazon.com is one of the world's largest bookstores, with a database containing over a million entries), software, photographs, on-line information of various sort (through electronic research databases such as Lexis-Nexis or WestLaw), legal and accounting services, and medical services. ${ }^{22}$ It is also possible to invest through online brokers, to gamble, and to open offshore bank accounts through the Internet. ${ }^{23}$ Many other types of goods and services, such as live and filmed entertainment, may be available over the Internet in the near future.

While the variety of goods and services offered over the Internet is growing rapidly, the scope of electronic commerce is still quite limited. The Interactive Services Association, an industry alliance, estimates that revenues from actual sales of tangible goods over the Internet and through online services totaled only $\$ 500$ million in $1995 .{ }^{24}$ By comparison, sales of all kinds in 1994 were $\$ 130$ billion..$^{25}$ On-line sales of services were somewhat more significant, and reached $\$ 1.6$ to $\$ 2.2$ billion in 1995 , but this figure includes the provision of Internet access itself (the sale of communications services), which needs to be distinguished from the provision of services over the net (a sale of content). ${ }^{26}$

Projections for the future growth of electronic commerce over the Internet indicate that it is likely to reach significant proportions rapidly. Sales of tangible personal property over the net in the 1998 holiday season were estimated at $\$ 2.3$ billion ${ }^{27}$ and are estimated to reach $\$ 6.6$ billion by $2000 .{ }^{28}$ While the figure for sales of tangible goods is still only $5 \%$ of current consumer mail order sales, it is likely to continue to grow rapidly as more people become connected to the Internet (the number of people with Internet access has doubled every year in the last decade). ${ }^{29}$ Two factors are crucial in enabling the continued growth of electronic commerce over the Internet: first, overcoming the current "bottleneck" of transfer speeds over widely

22 Id. § 3.2, at 7-10; see also Horner \& Owens, note 1, at 518 .

23 Id. $\S \S 3.2 .9-3.2 .12$, at 9-10.

24 ISA White Paper, note 5, at 213.

25 Id.

${ }^{26}$ Id.; see also Luc Soete \& Karin Kamp, The "BIT TAX": The Case for Further Research, Aug. 12, $1996<\mathrm{http}: / / \mathrm{www}$. ispo.cec.be/cgi-bin/vdk. . .aec2cb 71-531/Search/2728472/ $16 \#$ HLO $>$ (This article may be accessed by going to the site <http://www.ispo.cec.be/topic/ simple.html> and entering the phrase "The Bit Tax" into the search form).

${ }^{27}$ John Simons \& Douglas A. Blackmon, Online Shopping Lifts Delivery Concerns' Volume, Wall St. J., Dec. 30, 1998, at A3.

28 ISA White Paper, note 5, at 213.

29 Id. at 214. 
available modems (the so-called "bandwidth" issue). ${ }^{30}$ With current speeds, a music $C D$, for example, would take two days to transmit over the Internet; in a few years this may take only 10-15 minutes. ${ }^{31}$ The second factor is the development of secure means of paying electronically over the Internet, without fear of interception by unauthorized users or of fraud (such as spending e-money twice). ${ }^{32}$

The Treasury White Paper identifies several key features of the Internet (and, more generally, the information superhighway) that are important from a tax perspective. When discussing these features, it is important to remember that they are not indispensable parts of the operation of the Internet, and some or all of them may be changed by government regulation if that is deemed necessary to achieve relevant goals, such as taxation. Section V discusses some possibilities for such changes.

First, the Internet is radically decentralized, has no physical location, and pays no regard to national boundaries. ${ }^{33}$ Users have no control over, and usually no knowledge of, the routes taken by the data they transmit over the net. Net administrators have no control over the type of information that travels over their computers; they are merely the transmission points that enable the system to operate.

Second, one key advantage of conducting electronic commerce over the Internet, and especially over the World Wide Web, is that sellers can have direct contact with consumers with no need for intermediaries-a phenomenon called "disintermediation." 34 Moreover, if e-money develops as predicted, the banking institutions that act as intermediaries for credit card sales can be largely avoided as well.

Third, the addresses on the Internet (the "domain-style names" such as kitchens.com) do not reveal who is responsible for maintaining the name..$^{35}$ Even if the address is not generic (like ".com") but contains a country code (".uk"), the real location of the computer carrying that address need not be in the United Kingdom at all. Moreover, it is easy to introduce new computers to the Internet and to move existing computers from one location to another.

Fourth, it is possible to use an Internet site by "remote control." 36 For example, in the KitchenCo hypothetical, both the server in Guyana and the mainframe in Argentina can be run from other loca-

\footnotetext{
30 Treasury White Paper, note 2, at 7.

31 Id.

32 Id. at $10-14$.

33 Id. at 17.

34 Id.

35 Id. at 17-18.

36 Id. at 18.
} 
tions, and there is no way to detect the location of the person actually running the computer.

These features potentially can be replicated with traditional mail order sales, since the postal service also is decentralized (each country has its own) and mail order sales do not require intermediaries (although banks or other issuers are needed for credit card transactions). The interactivity, speed, and direct payment options of electronic commerce over the Internet, however, mean that it potentially can be used in ways that were not possible with traditional mail order sales. Thus, as Frances Horner and Jeffrey Owens point out, while traditional mail order sales posed a challenge to tax administrators, they could be dealt with by the current system because the scope of the problem was limited by the inherent disadvantages of the mail order method (slowness and lack of interactivity). ${ }^{37}$ Moreover, the audit trail of a catalog retailer was potentially easier to follow than the trail of an Internet merchant.

Electronic commerce thus poses a challenge to the traditional international tax regime. Under the traditional regime, tax jurisdiction is based on either formal residence or physical presence in a taxing jurisdiction. As can be seen in the KitchenCo example, however, electronic commerce makes it relatively easy for taxpayers to establish their formal residences in tax havens (such as Guyana), while production activities can take place in jurisdictions that do not tax such activities (such as Bermuda or Malaysia). Moreover, electronic commerce makes it easy to sell goods or services into a Demand Jurisdiction (like the United States in the example) without establishing any physical presence therein, and therefore the Demand Jurisdiction will not have the right to tax the seller under currently accepted principles. Thus, under current rules, income from electronic commerce may be able to escape taxation to a large extent, or even altogether. If electronic commerce grows at its projected rate, such an outcome could have serious adverse implications for the ability of jurisdictions to sustain the income tax base.

Sections IV and V are devoted to discussing, respectively, how the Treasury White Paper proposes to address this problem, and my suggestions for an alternative solution. First, however, it is necessary to establish a normative framework to determine whether the undertaxation of electronic commerce is a problem.

37 Horner \& Owens, note 1, at 517. 


\section{Two Principles of International Taxation}

A. Defining the Tax Base: The Single Tax Principle

International income taxation involves two basic questions: What is the appropriate level of taxation that should be levied on income from cross-border transactions? How are the resulting revenues to be divided among taxing jurisdictions? The answer to the first question is the Single Tax Principle: Income from cross-border transactions should be subject to tax once (that is, neither more nor less than once). The Single Tax Principle thus incorporates the traditional goal of avoiding double taxation, which was the main motive for setting up the international tax regime in the 1920's and 1930's. ${ }^{38}$ Taxing crossborder income once also means, however, that it should not be undertaxed or (at the extreme) be subject to no tax at all.

The appropriate rate of tax for purposes of the Single Tax Principle is determined by the second principle of international taxation, the Benefits Principle. The Benefits Principle, discussed below, ${ }^{39}$ assigns the primary right to tax active business income to source jurisdictions and the primary right to tax passive income to residence jurisdictions. Therefore, the rate of tax for purposes of the Single Tax Principle is generally the source rate for active business income and the residence rate for passive (investment) income. When the primary jurisdiction refrains from taxation, however, residual taxation by other (residence or source) jurisdictions is possible, and may be necessary to prevent undertaxation. ${ }^{40}$ Such residual taxation means that all income from cross-border transactions, under the Single Tax Principle, should be taxed at least at the source rate (which tends to be lower than the residence rate), but at no more than the residence rate. ${ }^{41}$

What is the normative basis for the Single Tax Principle? As an initial matter, this Article assumes that most countries would like to maintain both a personal income tax and a corporate income tax. The reasons for having both a personal income tax and a corporate income

38 Thomas S. Adams, Interstate and International Double Taxation, in Lectures on Taxation 101 (Roswell Magill ed., 1932) [hereinafter Double Taxation].

39 See Section II.B.

40 The reasons why undertaxation is undesirable are discussed below, at text accompanying notes $43-44$.

41 Under current rate structures (discussed at text accompanying notes 55-57), this translates into a minimum tax of about $30 \%$ and a maximum tax of about $60 \%$. (Nominal rates are used rather than effective rates, because they best represent a consensus on how much tax is due). The discussion assumes that shareholders should get credit for taxes paid by corporations, to prevent taxation by both source and residence jurisdictions. The credit should be given even when residence-based taxation is imposed because of the application of subpart F and similar rules. That is, if (under the proposal developed in Section V), a tax is imposed by a Demand Jurisdiction, credit for the tax should be given by jurisdictions taxing the seller or its shareholders under the CFC regime. 
tax have been discussed extensively elsewhere, and are not repeated here. ${ }^{42}$ For purposes of justifying the Single Tax Principle, it is sufficient that most countries in fact maintain their existing personal and corporate income taxes. 43

Given a preference for imposing both a personal and a corporate income tax on domestically derived income of individuals and corporations, it becomes relatively easy to establish why the Single Tax Principle is justified as a goal of the international tax regime, on both theoretical and practical grounds. From a theoretical perspective, if income derived from cross-border transactions is taxed more heavily than domestic income, the added tax burden creates an inefficient incentive to invest domestically. This proposition is widely accepted and underlies the effort, which by now is about a century old, to prevent or alleviate international multiple taxation.

The corollary also holds true: If income from cross-border transactions is taxed less heavily than domestic income, this creates an inefficient incentive to invest internationally rather than at home. The deadweight loss from undertaxation is the same as that from overtaxation. ${ }^{44}$

In addition, there is also a strong equity argument against undertaxation of cross-border income, which applies to income earned by individuals. From an equity perspective, undertaxation of cross-border income violates both horizontal and vertical equity when compared to higher tax rates imposed on domestic source income, and in particular on domestic labor income. In this case, the argument that equity vio-

42 Fundamentally, the income tax seems superior to the consumption tax on grounds of equity or fairness. Alvin C. Warren, Jr., Would a Consumption Tax Be Fairer Than an Income Tax?, 89 Yale L.J. 1081 (1980). The justification for a corporate income tax depends on whether it is viewed as an advance payment of the tax on shareholders, or as an independent tax, which, in turn, depends on whether one believes the "old" or "new" view of dividend taxation. See John G. Head, Company Tax Systems: From Theory to Policy, in Company Tax Systems 1, 1-21 (John G. Head \& Richard Krever eds., 1997) (Austrl. Tax Research Found. Conf. Series No. 18).

43 The definition of the tax base as income or consumption is conceptually a different question from the jurisdiction to which the tax base belongs. A consumption tax does not necessarily belong to the jurisdiction in which consumption takes place (see, for example, an origin-based VAT), while an income tax does not necessarily belong to the jurisdiction in which production takes place.

44 This proposition is widely accepted among economists as capital export neutrality. See, e.g., Treasury Dep't, International Tax Reform: An Interim Report 2 (1993), reprinted in Daily Tax Rep. (BNA), Jan 22, 1993, at L-1, L-3; Staff of Joint Comm. on Tax'n, Factors Affecting the International Competitiveness of the United States 241-43 (1991), reprinted in Daily Tax Rep. (BNA), June 4, 1991, at S-1, S-78 to S-79. The opposite view, capital import neutrality, which implies that all income should be taxed at the source rate even if the source rate is zero, is widely viewed as resting primarily on competitiveness (rather than efficiency) concerns. Id. Such competitiveness issues are best addressed by coordinated actions to limit tax competition, such as those envisaged in OECD, Harmful Tax Competition: An Emerging Global Issue (1998). 
lations tend to turn into efficiency issues does not hold, ${ }^{45}$ because labor is less mobile than capital and wage earners typically do not have the ability to transform their domestic wages into foreign source income.

On a practical level, the Single Tax Principle can be justified because double taxation leads to tax rates that can be extremely high and tend to stifle international investment. Zero taxation, on the other hand, offers an opportunity to avoid domestic taxation by investing abroad, and therefore threatens to erode the national tax base. T.S. Adams, the architect of the foreign tax credit and a major influence in shaping the international tax regime, recognized both of these propositions in the 1920's. In justifying the foreign tax credit, Adams wrote "the state which with a fine regard for the rights of the taxpayer takes pains to relieve double taxation, may fairly take measures to ensure that the person or property pays at least one tax. ${ }^{146}$ Contrary to an exemption system, Adams' credit operated to eliminate double taxation by both source and residence jurisdictions, but preserved residual residence-based jurisdiction to enforce the Single Tax Principle.

The practical justification for the Single Tax Principle can be seen most easily if one imagines a world with only two countries, $A$ and $B$, and only two companies, $X$ (a resident of $A$ ) and $Y$ (a resident of $B$ ). If both $A$ and $B$ tax the foreign source income of their residents and domestic source income of foreigners, and neither gives relief from double taxation, then both $X$ and $Y$ would minimize their taxes by only deriving domestic source income (since any foreign tax would by definition be an added burden). 47 The result would be adequate revenues collected by both $A$ and $B$, but no cross-border trade or investment.

On the other hand, suppose both $A$ and $B$ exempted from tax both foreign source income and domestic source income of foreigners (a not inconceivable proposition in many developing countries, which tax residents territorially and grant tax holidays to foreign investors). ${ }^{48}$ In that case, the way for both $X$ and $Y$ to minimize their taxes would be to derive their entire income from cross-border transactions. The result would be adequate cross-border trade, but no revenues for $A$ or

45 See, e.g., Boris I. Bittker, Equity, Efficiency, and Income Tax Theory: Do Misallocations Drive Out Inequities, 16 San Diego L. Rev. 735 (1979).

46 Michael J. Graetz \& Michael M. O'Hear, The "Original Intent" of U.S. International Taxation, 46 Duke LJ. 1021, 1039 n.72 (1997) (quoting Adams, Double Taxation, note 38, at 112-13) (emphasis added).

47 The proposition holds even if the foreign tax is deductible.

48 Ireland, for example, grants foreign investors a tax holiday. Arthur Andersen \& Co., Tax and Trade Guide: Republic of Ireland 44-45, 97-101 (2d ed. 1979). 
$B$. In a world in which international trade and investment are important, but taxes (unlike tariffs) cannot be reduced to zero, the Single Tax Principle is the best option.

\section{B. Dividing the Tax Base: The Benefits Principle}

Having defined one goal of the international tax regime as taxing cross-border income once, the next question is how to divide that base among the various jurisdictions laying claim to it. The Benefits Principle states that the residence jurisdiction has the primary right to tax passive (investment) income, while the source jurisdiction has the primary right to tax active (business) income. As explained above, this division also determines the appropriate rate of tax for purposes of the Single Tax Principle. ${ }^{49}$

This distinction also can be justified on both theoretical and pragmatic grounds. On a theoretical level, the Benefits Principle makes sense because it is primarily individuals who earn investment income, whereas it is primarily corporations that earn business income. In the case of individuals, residence-based taxation makes sense. First, residence is relatively easy to define in the case of individuals. Second, because most individuals are part of only one society, distributive concerns can be addressed most effectively in the country of residence. Third, residence overlaps with political allegiance, and in democratic countries, residence taxation is a proxy for taxation with representation..$^{50}$

In the case of multinational corporations, source-based taxation seems generally preferable. First, the grounds for taxing individuals on a residence basis do not apply to corporations. The residence of corporations is difficult to establish and relatively meaningless. Residence based on place of incorporation is formalistic and subject to the control of the taxpayer, while residence based on management and control also can be manipulated. Moreover, multinationals are not part of a single society and their income does not belong to any particular society for distributive purposes. Finally, multinationals can exert significant political influence in jurisdictions other than the residence jurisdiction of their parent company, and therefore the concern about taxing foreigners who lack the ability to vote is less applicable to them.

Second, source-based taxation is consistent with a benefits perspective on justifying tax jurisdiction. Source jurisdictions provide signifi-

\footnotetext{
49 See text accompanying notes 38-39.

so These arguments are developed more extensively in Reuven S. Avi-Yonah, The Structure of International Taxation: A Proposal for Simplification, 74 Tex. L. Rev. 1301 (1996) [hereinafter Proposal].
} 
cant benefits to corporations that carry on business activities within them. Such benefits include the provision of infrastructure or education, as well as more specific government policies such as keeping the exchange rate stable or interest rates low. These benefits justify source-based corporate taxation in the sense that the host country's government bears some of the costs of providing the benefits that are necessary for earning the income. As T.S. Adams wrote in 1917, "A large part of the cost of government is traceable to the necessity of maintaining a suitable business environment." ${ }^{1} 1$ These costs justify imposing a tax as compensation to the government bearing them. 52

On a more pragmatic level, as Adams also observed, since the source jurisdiction has by definition the "first bite at the apple," that is, it has the first opportunity to collect the tax on payments derived from within its borders, it would be extremely difficult to prevent source jurisdictions from imposing the tax. "Every state insists upon taxing the non-resident alien who derives income from source [sic] within that country, and rightly so, at least inevitably so."s3 Thus, as O'Hear and Professor Graetz observe, even if economists tend to prefer pure residence-based taxation, this recommendation is unlikely to be followed in practice. ${ }^{54}$ This is particularly the case for business income derived from large markets, in which case there is little fear that the foreign investor will abandon the market because of source-based taxation. For portfolio investment, however, even large source countries like the United States have tended to abandon it for fear of driving away mobile capital. 55 Thus, business income is a better candidate for source-based taxation than investment income.

The division between active (mostly corporate) and passive (mostly individual) income also makes sense because it is congruent with the Single Tax Principle, since most of the rate divergence among taxing jurisdictions arises in the individual income tax, while corporate tax

51 Graetz \& O'Hear, note 46, at 1036 (quoting Thomas S. Adams, The Taxation of Business, 11 Nat'l Tax Ass'n Proc. 185, 186 (1917)).

52 But see Joseph M. Dodge, A Combined Mark-to-Market and Pass-Through Corporate-Shareholder Integration Proposal, 50 Tax L. Rev. 265 (1995) (arguing that benefits can only justify user fees and not an income tax); Robert A. Green, The Future of SourceBased Taxation of the Income of Multinational Enterprises, 79 Cornell L. Rev. 18 (1993) (same). But this view assumes that benefits are not correlated with income, which is true for some types of benefits (for example, the right to do business in a jurisdiction) but not for others (for example, infrastructure or education). The benefits provided by residence jurisdictions per se do not justify an income tax, which is another reason to prefer sourcebased taxation of corporations.

53 Graetz \& O'Hear, note 46, at 1037 (quoting Thomas S. Adams, Interstate and International Double Taxation, 22 Nat'l Tax Ass'n Proc. 193, 197 (1929)).

54 Graetz \& O'Hear, note 46, at 1102-03.

55 See, e.g., IRC $\$ 871(\mathrm{~h})$ (repealing tax on interest of nonresident aliens received from certain portfolio debt investments). 
rates have tended to converge. The top marginal personal income tax rate among OECD member countries varied in 1995 from $11.5 \%$ (Switzerland) to $60 \%$ (Netherlands). ${ }^{56}$ This variability is acceptable for purposes of the Single Tax Principle, because under the Benefits Principle most income earned by individuals in cross-border transactions is investment income that generally is subject only to residence country tax. Therefore, the residence country rate typically determines the single tax rate for investment income..$^{57}$

Corporate tax rates, on the other hand, do not vary so widely (and also tend to be flat, rather than progressive). Among OECD member countries, in 1995 the corporate tax rate ranged from 25\% (Finland and Turkey) to $45 \%$ (Germany, on undistributed income), but 19 out of 24 member countries had rates in the $29 \%$ to $40 \%$ range. 58 Thus, for purposes of the Single Tax Principle, the rate applied is generally the residence rate for individual (mostly investment) income and a rate in the $30-40 \%$ range for corporate (mostly business) income. It is congruent with both the Single Tax and Benefits Principles, however, to have residual taxation by residence or source jurisdictions in cases where the jurisdiction that has the primary right to tax under the Benefits Principle refrains from doing so. Thus, under the Single Tax and Benefits Principles, all income from cross-border taxation under current rate structures should be taxed at a rate between approximately $30 \%$ (the lower end of the source rates) and approximately $60 \%$ (the higher end of the residence rates).

Neither the Single Tax Principle nor the Benefits Principle provides a clear answer to the question of how to divide the corporate income tax base among the various jurisdictions providing benefits. Market prices can provide an answer when transactions are at arm's length, but not when they are between related parties (and there are no comparable arm's length transactions). ${ }^{59}$ In addition, the Single Tax Principle requires that taxation be imposed even on income derived from

56 Jeffrey Owens, Tax Reform for the $21^{\text {st }}$ Century, 14 Tax Notes Int'l 583, 585 tbl.1 (Feb. $17,1997)$. Switzerland also has cantonal income taxes, so its effective rate may be higher, depending on the canton.

57 If, however, the residence rate is zero or close to it, residual source-based taxation is acceptable to maintain the Single Tax Principle, as explained above. The discussion in the text assumes an integrated regime in which credit is given to shareholders for corporate taxes paid, to prevent double (source and residence) taxation of dividends.

58 Owens, note 56, at 590 tbl. 6 . (Switzerland and Norway have rates below $25 \%$, which may be increased by subnational taxes).

59 In theory, even when the market divides profits, this does not provide a clear answer. For example, assume $A$ is a resident of country $S$ and is selling goods to unrelated party $B$, a resident of country $D$, which, in turn, sells them to unrelated consumers in country $D$. Although the market price divides the profit between $A$ and $B$, it is not obvious that $S$ is not providing benefits to $B$ or $D$ to $A$, and therefore that $S$ should be limited to taxing $A$, and $D$ to taxing $B$. In practice, however, the permanent establishment rule (discussed in 
a jurisdiction that chooses not to levy a tax in return for the benefits it provides. Both of these issues are addressed in the electronic commerce context in Section V.

The rise of electronic commerce undermines both of the principles defined above. The Single Tax Principle is undermined because electronic commerce makes it much easier, in the ways explained in Section V.A. to earn income from cross-border transactions that is not subject to tax by any jurisdiction. The Benefits Principle is undermined because under current rules income from electronic commerce (active business income) may not be taxable by the source jurisdiction. The remainder of this Article articulates these problems and discusses two alternative solutions: a residence-based regime, as proposed by Treasury, and my proposal for a (largely) source-based regime based on the imposition of a withholding tax by the Demand Jurisdiction.

\section{The Treasury White Paper: A Residence-Based Regme}

Treasury should be commended for undertaking the extremely important task of being the first tax administration to set forth its views on the tax policy implications of global electronic commerce. Published in November 1996, the White Paper represents the best summary so far of the international tax issues raised by electronic commerce. ${ }^{60}$ It provides fewer answers than questions, but that is natural in a document officially labeled a "discussion paper," and given the current state of the scholarship on this issue. As a framework for discussion, it is excellent.

The White Paper is divided into nine sections. After an introduction, sections two to five summarize the technical features of electronic commerce in a way that is easily accessible to a layperson, and that forms the basis for much of the discussion above. Sections six to eight discuss, respectively, general tax policy and administration considerations to be applied to electronic commerce, substantive tax law issues, and administration and compliance issues. Section nine is the conclusion. The core of the White Paper is section seven, which addresses most of the substantive tax issues mentioned above: The general impact on the international tax regime, permanent establishment, classification of income, and sourcing of income from services, especially global services like global trading.

In general, the White Paper concludes that existing tax concepts likely can be adapted to address the problems raised by electronic

Section V.A.) limits $S$ to taxing $A$, and $D$ to taxing $B$ in these circumstances, and this seems a good practical solution.

60 Treasury White Paper, note 2, § 1, at 3-4. 
commerce. ${ }^{61}$ Thus, for example, the White Paper addresses the permanent establishment issue in terms of the traditional definitions, such as whether a server can be regarded as a warehouse that qualifies for the exception for "facilities solely for the purpose of storage, display, or delivery of goods."62 The White Paper concludes that "[e]xamination and interpretation of the permanent establishment concept in the context of electronic commerce may well result in an extension of the policies and the resulting exceptions to electronic commerce." 63 I discuss below whether that is sufficient. ${ }^{64}$ Similarly, in discussing classification of income, the White Paper endorses the concepts underlying the proposed regulations on classifying income from computer software (whose primary author, Bruce Cohen, was also the primary author of the White Paper). ${ }^{65}$ These regulations, ${ }^{66}$ maintain the traditional distinction among services, royalties, and sales and seek to apply it to income from software. The White Paper suggests that similar principles may apply to classifying all income from electronic commerce, especially in the case of goods or services that can be digitized. ${ }^{67}$

Thus, the White Paper is in general quite conservative, rejecting the need for any radical rethinking of traditional tax concepts as a result of the rise of electronic commerce. There is, however, one major exception to this overall trend. Section 7.1.5 is entitled "The ascendancy of residence-based taxation," and argues that the rise of electronic commerce will "accelerate" a trend towards preferring residence-based taxation over source-based taxation, because it will increase the difficulty of the latter:

The growth of new communications technologies and electronic commerce will likely require that principles of residence-based taxation assume even greater importance. In the world of cyberspace, it is often difficult, if not impossible, to apply traditional source concepts to link an item of income with a specific geographical location. Therefore, source based taxation could lose its rationale and be rendered obsolete by electronic commerce. By contrast, almost all taxpayers are resident somewhere ... United States tax policy has already recognized that as traditional source prin-

61 Id. $\S 6.2$, at 17 , and $\S 9$, at 35 .

62 Id. at 23.

63 Id.

64 See Section V.A.

65 Id. $\$$ 7.3.3., at 25-26.

66 See Section V.B. for discussion of these regulations.

67 Id. \$ 7.3, at 24-25. 
ciples lose their significance, residence-based taxation can step in and take their place. This trend will be accelerated by developments in electronic commerce where principles of residence-based taxation will also play a major role. $6 \mathrm{~s}$

This section represents the main policy recommendation in the White Paper, and therefore merits an extended discussion. The following issues need to be addressed: (1) whether the recommendation to shift to a residence-based tax regime is consistent with the current international consensus and with U.S. tax policy, (2) whether this is the correct way to go as a policy matter, and (3) whether this is required by the rise of computer-based electronic commerce.

First, the recommendation to tax income from electronic commerce primarily or exclusively on a residence basis is inconsistent with the generally accepted international consensus, as embodied in tax treaties and in the U.S. international tax regime. As discussed above, ${ }^{69}$ that consensus is based on the Benefits Principle, which reflects a compromise reached in the 1920's on dividing the tax base between residence and source jurisdictions, allocating the right to tax active income primarily to the source jurisdiction. ${ }^{70}$

As noted by O'Hear and Professor Graetz, the "original intent" underlying U.S. international tax policy was based on a preference for source-based taxation of active income. ${ }^{71}$ Moreover, it is hard to detect a trend toward more residence-based taxation in recent U.S. tax policy, despite the suggestion to the contrary in the White Paper. ${ }^{72}$ As far as the U.S.'s own claims to source-based taxation of active income, the U.S. trade or business threshold has always been quite low, and there is no indication that it or the permanent establishment threshold has been raised recently. To the contrary, as the United States enters into more tax treaties with developing countries, the latter threshold tends to be lower. ${ }^{73}$

The White Paper mentions two indications of the trend toward residence-based taxation: the source rule for sales of noninventory property and the rules for space and ocean activity. ${ }^{74}$ This analysis is

68 Id. $\S 7.1 .5$, at 20 ; see also the discussion of the source of services income in id. $\$ 7.4 .2$, at 28 .

69 See discussion in Section II.B.

70 See Avi-Yonah, Proposal, note 50, at 1349-50.

71 Graetz \& O'Hear, note 46, at 1037-38.

72 Treasury White Paper, note $2, \S 7.1 .5$, at 19-20.

73 Compare Income Tax Treaty, Sept. 12, 1989, U.S.-India, art. V, 2 Tax Treaties (CCH) II 4203.11 (deferring permanent establishment to include oil rigs installed for 120 days), with U.S. Model Income Tax Treaty, Sept. 20, 1996, art. 5(3), 1 Tax Treaties (CCH) \} 2 1 4 [hereinafter U.S. Model Treaty] (one-year threshold).

74 IRC \$§ 865(a), 863(d). 
misleading; the source rule for sales of noninventory property has always favored residence-based taxation because of the difficulty of establishing basis for nonresident taxpayers. ${ }^{75}$ The space and ocean activity rules reflect a sense that the income truly has no source in the sense of being earned outside all taxing jurisdictions. Income from cyberspace, on the other hand, does have a source in the traditional sense because both the production activities and the consumption that produce it take place in a physical location outside cyberspace. In that sense, income from cyberspace is more like international communications income, which under a rule enacted at the same time as the rule for space and ocean activities, ${ }^{76}$ is taxed on a source basis. In the case of a U.S. person, $50 \%$ of the income is sourced in the United States with foreign tax credits granted for any tax on the other $50 \% .{ }^{77}$ In the case of a foreign taxpayer, the income is taxed in the United States if it is attributable to a fixed place of business in the United States. ${ }^{78} \mathrm{~A}$ preference for residence-based taxation is also incompatible with the recent U.S. trend to expand deferral. ${ }^{79}$ The suggestion in the White Paper that income from electronic commerce should be taxed on a residence basis thus deviates from the accepted international consensus on how to tax active business income, in a way that represents a sharp departure from previous trends.

Second, as discussed above ${ }^{80}$ the international consensus reflects the Benefits Principle, which has a policy rationale behind it. Most active business income from international transactions is earned by multinational corporations, and it is not at all clear what residence means in the case of a multinational, especially now that the shareholder base, sources of capital, and location of business activities of multinationals may all be dispersed over many taxing jurisdictions. Even the White Paper admits that "a review of current residency definitions and taxation rules may be appropriate" in light of electronic commerce. ${ }^{81}$

75 Commissioner v. Wodehouse, 337 U.S. 369, 388-89 n.12 (1949).

76 IRC § 863(d).

77 IRC $\S 863(\mathrm{e})(1)(\mathrm{A})$, enacted by The Tax Reform Act of 1986, P.L. 99-514, $\S 1213(\mathrm{a})$, 100 Stat. 2093.

78 IRC $\$ 863(\mathrm{e})(1)(\mathrm{B})(\mathrm{ii})$.

79 This trend can be seen in the repeal of IRC $\S 956 \mathrm{~A}$ by the Small Business Job Protection Act of 1996, P.L. 104-188, § 1501(a)(2), 110 Stat. 1755; the elimination of the PFIC/ CFC overlap by the Taxpayer Relief Act of 1997, P.L. 105-34, $\$ 1122$ (a), 111 Stat. 788, which added IRC $\S 1296(\mathrm{e})$, redesignated as $\S 1296(\mathrm{f})$ in 1998 by P.L. 105-206, $\S 6011$ (b)(1); and the recent dispute around Notice 98-11, 1998-6 I.R.B. 13, and the regulations thereunder, Temp. Reg. $\$ 1.954-9 \mathrm{~T}$, culminating in their withdrawal under fire in Notice 98-35, 1998-27 I.R.B. 35.

80 See discussion Section II.B.

81 Treasury White Paper, note $2, \S 7.1 .5$, at 20 . 
Third, the relative meaninglessness of corporate residency leads to the third problem with a preference for residence: While the White Paper emphasizes the problems that electronic commerce gives rise to in establishing the source of income, even more difficult problems arise in establishing the residence of corporate taxpayers. As emphasized in Section II, electronic commerce can be carried out from any location on the globe that is connected to the Internet. Thus, it is all too easy to set up the parent corporation of a multinational engaging in electronic commerce in a tax haven. For example, Guyana (where KitchenCo's parent is incorporated) is a leading source of telephone pornography. ${ }^{82}$ If the United States applies its traditional residence concepts, which look to the country of incorporation of the corporate taxpayer to establish residence, such entities would not be subject to U.S. tax on their income from electronic commerce, and in the absence of source-based taxation, would not be subject to any tax. In fact, the United States was obliged recently to change its tax rules to prevent the tax-free reincorporation of U.S. companies in a tax haven. ${ }^{83}$ This rule works in the case of a business incorporated in the United States, but an Internet-based business does not have to be started in the United States-it can be started anywhere.

It could be argued that Internet-based businesses would be unlikely to leave the United States, since it has so far proved to be the home of by far the largest number of such businesses. Even if this trend continues (and other countries are becoming increasingly friendly to such businesses), in order to avoid residence-based tax rules, the only necessary shift is a corporation's formal residency; none of the actual business operations need to be moved, and no employees need to leave the United States. One needs only recall the massive shifting of formal residency to New Jersey and then to Delaware as these jurisdictions adopted favorable corporate laws. ${ }^{84}$ It does not seem very far fetched to imagine that companies may choose jurisdictions other than the United States as their formal location of incorporation, if their shares can continue to trade freely on most exchanges and the costs of doing so are minimal when compared to the tax advantages.

The country where an Internet-based company is incorporated does not even have to be a traditional tax haven. Many developed coun-

82 Cybersex: An Adult Affair, The Economist, Jan. 4, 1997, at 64.

83 See Notice $94-46,1994-1$ C.B. 356 , which was prompted by the tax-free reincorporation of a U.S. public company (Helen of Troy, Inc.) engaged in selling cosmeties in a tax haven jurisdiction.

84 See, e.g., Phillip I. Blumberg, The Multinational Challenge to Corporation Lav 56-58 (1993) (discussing New Jersey's role in this evolution); Henry N. Butler, Nineteenth-Century Jurisdictional Competition in the Granting of Corporate Privileges, 14 J. Legal Stud. 129 (1985) (discussing the origins of jurisdictional competition for corporate situs). 
tries, such as the Netherlands ${ }^{85}$ and Belgium, offer special tax regimes for holding companies, designed specifically to attract the headquarters of multinationals. ${ }^{86}$ Such "headquarters tax havens" do not tax holding companies (beyond a minimal user fee) on income derived from their foreign operating subsidiaries. In addition, they offer advanced corporate and securities laws, so that corporations incorporating there do not have to bear the stigma associated with traditional offshore tax havens. ${ }^{87}$ Even if Internet-based companies like KitchenCo are not set up in Guyana, they may well be set up in the Netherlands, and this possibility remains as long as even a single developed country offers such a regime. ${ }^{88}$

Other countries look to the corporation's place of management and control to establish corporate residence, but the rise of intranets may render that approach obsolete. There is no longer any need for corporate boards to meet in one physical location, and corporate management can be dispersed in many different countries (including headquarters tax havens) and communicate via e-mail or video conferencing on secure intranets. Where is such a company's place of management and control? And even if the place of management and control can be established, it does not have to be in an offshore tax haven where managers might not want to live; headquarters tax havens offer all the amenities of a developed country, which might appeal to management who desire to live in the place of management and control, in places such as Brussels.

Conceivably, one could look to the residence of shareholders to establish the residence of corporations. The shares of most multinationals, however, now trade on several exchanges in different countries, so there would not be a single corporate residence, but many. ${ }^{89}$ Taxing such a multinational on a residence basis essentially would require a form of pass-through integration, with shareholders taxed currently on the earnings of the multinational. 90 That result would be very difficult to achieve when the shares are publicly traded, and it would be hard

85 Coopers \& Lybrand, Global Tax Network, 1997 International Tax Summaries N-11 (George J. Yost III ed., 1997).

86 Id. at B-34 to 35.

87 See Kurt A. Wagner, Comment: U.S. Taxation of Foreign Income: The Use of Tax Havens in a Changing Tax Environment, 18 S.III. U.L.J. 617, 620 (1994).

88 Even in the case of the OECD, which recently announced measures against harmful tax competition, the possibility of a single defection undermining the effort is ever present. In fact, Luxembourg and Switzerland (two established "headquarters tax havens") announced that any measures adopted by the OECD will not apply to them. OECD, note 44 , ann. II (1998).

${ }^{89}$ See Amir Licht, Regulatory Arbitrage for Real: International Securities Regulation in a World of Interacting Securities Markets, 38 Va. J. Int'l L. 563 (1998).

90 See Green, note 52, at 70 . 
for the shareholders to obtain the requisite information from a foreign corporation they would not control. The U.S. experience with taxing PFICs has not been encouraging in this regard.91 Taxing shareholders on a mark-to-market basis for publicly traded shares has been suggested as a possible alternative, but one that seems unlikely to be widely adopted, especially since it would have to be combined with the foreign tax credit, unless all countries were to give up sourcebased taxation..$^{92}$ The administrative complexities are immense, and probably unmanageable for most individual shareholders.

Thus, adopting the White Paper's suggestion and taxing income from electronic commerce on a residence basis appears to depart from the current international consensus and from the current U.S. international tax regime, both of which broadly reflect the Benefits Principle. Moreover, it does not appear to make sense as a way of taxing this kind of income, precisely because the nature of electronic commerce makes it extremely easy to locate the residence of taxpayers earning such income in tax havens. If there is no source-based taxation, there is no taxation of the income from electronic commerce, which violates the Single Tax Principle.

The White Paper suggests that shifting to residence-based taxation is necessary because electronic commerce raises special difficulties in sourcing income. ${ }^{93}$ Sourcing is not really the problem, however: The source of income from electronic commerce generally can be found in each taxing jurisdiction in which people (or computers) enter into cyberspace in order to conduct electronic commerce. The real problem is not defining the source, but rather apportioning the income among all the jurisdictions that have a source-based right to it, because their individual residents participate in the production or consumption activities that give rise to the income. That problem is indeed difficult even for traditional commerce, and it is rendered somewhat more difficult by electronic commerce. But it is not insoluble, and I discuss a possible outline for a solution in Section V. The problem of taxing income from electronic commerce on a residence basis without enabling a significant amount of it to escape tax altogether seems at least as difficult, and probably more so.

In addition, the discussion in the White Paper seems to assume that - if one adopts a residence-based approach, one can escape the need to source income altogether. But that would be true only if all countries

91 See, e.g., Thomas D. Fuller, The Phickle Finger of Fate: Many Questions, Few Answers, 98 TNI 225-16, Nov. 23, 1998, available in LEXIS, Fedtax Library, TNI File ("Whisper the acronym 'PFIC' into the ear of any U.S. tax planner, and you're sure to elicit a frisson of terror."). For rules covering PFICs, see IRC $\$ \S 1291-1298$.

92 See Dodge, note 52, at 362-63, 372.

93 Treasury White Paper, note $2, \S 7.1 .5$, at 20. 
adopted this approach and none taxed this income on a source basis. If this assumption, which seems highly unlikely given the wide acceptance of the Benefits Principle, is not met, then to avoid double taxation, the residence country would have to grant either an exemption to foreign source income (which depends on source) or a foreign tax credit. In the latter case, unless the residence country were willing to grant a credit with no limitation (thus inviting source countries to raise their tax rates on electronic commerce at the expense of the residence country), sourcing would be required to determine the foreign tax credit limitation. Thus, whatever the difficulties in determining the source of income, one cannot avoid this task in a world where some jurisdictions apply source-based taxation.

The reaction of other governments to this suggestion of the White Paper is also instructive. ${ }^{94}$ They tended to endorse or reject it based on a calculation of whether it would benefit or harm them in terms of the revenue expected to be derived from electronic commerce. Countries whose residents are expected to earn a significant amount of this income were predictably more favorable to the White Paper's proposals than were countries that expected to be able to tax it primarily on a source basis. ${ }^{95}$ It may be that such thinking underlay the U.S. preference as well; currently, a residence-based rule would be expected to benefit the United States because its residents are leaders in the electronic commerce arena. But if the rule were indeed to be adopted, that could change very quickly, as corporations and computers could be shifted to residence jurisdictions with more hospitable tax laws. One need only observe the case of shipping, which traditionally has been taxed on a residence basis, based on the country where the ships are registered: Most of the income is earned by ships registered in tax havens and thus escapes taxation. ${ }^{96}$ Thus, if the White Paper proposal is guided by such considerations, it seems short-sighted, and unlikely to be accepted by other countries with different revenue projections.

If, however, source-based taxation of active business income from electronic commerce continues to be the norm, in accordance with the Benefits Principle, one needs to confront the thorny issues it raises: What is to be the threshold for taxing such income? How should various types of such income be differentiated from each other? And how is the income to be apportioned among the jurisdictions legitimately

94 See, e.g., Austl. Tax'n Office (ATO), Electronic Commerce Project, Tax and the Internet (Aug. 1997) (visited Oct. 28, 1998) <http://www.ato.gov.au/ecp/ecp.htm> (rejecting a residence-based approach).

95 See, e.g., Susan M. Lyons, ABA Discusses Tax Treaties at Mid-Year Meeting, 97 TNI 13-36, Jan. 21, 1997, available in LEXIS, Fedtax Library, TNI File.

96 See Philip J. Loree, Shipping Federation Chairman Testifies on Competitiveness, 91 TNI 39-26, Sept. 12, 1991, available in LEXIS, Fedtax Library, TNI File. 
claiming to be its source, in a way that ensures compliance with the Single Tax Principle?

\section{Three Proposals Toward A Solution}

My proposals address the three most difficult challenges posed by electronic commerce to the current international tax regime: (1) setting the threshold for taxing active business income, (2) distinguishing royalties from income from services and sales, and (3) transfer pricing. These proposals are intended to apply only to income from electronic commerce.97 The reason for limiting the proposals is that the problems raised by electronic commerce are in some ways unique to it, and do not necessarily spill over to other forms of commerce. ${ }^{93}$ Thus, for example, it seems unnecessary at this point to modify the permanent establishment rule, which is embedded in all tax treaties, ${ }^{99}$ just to deal with the specific problems posed by electronic commerce. If the proposals are so limited, it will be unnecessary to renegotiate all existing tax treaties (for example, to redefine permanent establishment), except to carve out electronic commerce from their scope.

While in general it may be advisable to have the same tax rules apply to different types of commerce to avoid tax-induced distortions in what type of commerce to engage in, in this case, the problem seems less acute. First, because of the nature of cyberspace, the line between electronic commerce and non-electronic commerce seems relatively easy to draw, so that classification issues are largely avoided. For purposes of the following proposals, if contact between a buyer and seller is made through cyberspace, the resulting income can be classified as resulting from electronic commerce.

Moreover, the problems discussed in this Article are more acute with respect to electronic commerce than to regular commerce. In particular, non-electronic commerce frequently gives rise to a permanent establishment in the Demand Jurisdiction, which makes taxation possible there. It is also more likely that residence-based taxation can be imposed on income from non-electronic commerce, because the major corporate taxpayers are established in major taxing jurisdictions. Thus, the level of taxation imposed on electronic commerce by the following proposals may be generally congruent with the results

97 It would make sense, however, to apply them to other forms of "remote" commerce, such as mail-order catalogues, which raise issues similar to electronic commerce.

98 Limiting the proposals in this fashion to deal with a particularly mobile form of business is similar to the current trend towards more schedular taxation, and in particular, taxing capital income differently from labor income because of its higher mobility.

99 OECD Comm. on Fiscal Affairs, Model Tax Convention on Income and on Capital, art. 5 (1992), reprinted in 1 Tax Treaties (CCH) \& 191 [hereinafter OECD Model Treaty]. 
for other types of commerce under the current regime. ${ }^{100}$ If that is the case, little tax-induced distortion in taxpayer behavior will take place, even though the allocation of the revenues may differ depending on the type of commerce involved.

It is possible that the type of problems discussed in this Article in the future will apply to non-electronic commerce as well, and therefore a broader application of the proposals will be justified.101 Should that be the case, it certainly would be possible to expand the scope of the proposals to other types of commerce as well, although that would involve much more significant changes in the current regime.

It should be noted at the outset that each of the proposals can be applied unilaterally and therefore do not require setting up some sort of multilateral forum, such as a "world tax organization." Coordination, however, would be advisable through organizations such as the OECD.

\section{A. Impermanent Establishments}

The White Paper and most other discussions of the impact of electronic commerce on the jurisdictional threshold for taxing active income tend to assume that it has to be taxed under the current definitions of that threshold. ${ }^{102}$ There are two relevant terms under current law: "U.S. trade or business," which is the jurisdictional threshold for nontreaty purposes, ${ }^{103}$ and "permanent establishment," which is the jurisdictional threshold for treaty purposes. ${ }^{104}$

The U.S. trade or business threshold traditionally has been relatively low; ${ }^{105}$ renting out two apartments in the United States may constitute a U.S. trade or business. ${ }^{106}$ It does seem to require some physical presence in the United States, however, and as the White Paper points out, electronic commerce can be carried out without any such presence from any location in the world.107 The White Paper thus suggests that merely engaging in electronic commerce with U.S. residents would probably not constitute a U.S. trade or business. ${ }^{108}$

100 Tax competition may be undermining the traditional regime as well and leading to undertaxation of all active business income. It may be possible to deal with this problem, however, in ways that are less radical than the proposals included herein. See OECD, note 44 , for a discussion of the problem and recommendations on how to address it. I intend to address these issues in a forthcoming paper on tax competition.

101 I hope to study this question in future work on the problem of tax competition.

102 Treasury White Paper, note $2, \S 7.1 .1$, at 19.

103 See id. § 7.2.1, at 21 .

104 See id. \$ 7.2.2, at 21 .

105 See generally IRC $\$ 864(b)$.

106 See generally Rev. Rul. 73-552, 1973-2 C.B. 226.

107 Treasury White Paper, note 2, \& 7.2.3.1, at 21-22.

108 Id. 
Even if a computer server used in electronic commerce were located in the United States, it will be impracticable to treat it as a U.S. trade or business, because the server can easily be located anywhere. ${ }^{109}$ Similarly, the operation of a computerized research service from outside the United States, which can be accessed electronically by U.S. residents, would likely not constitute a U.S. trade or business unless there were U.S. personnel providing marketing or support services. ${ }^{110}$

The permanent establishment threshold under treaties tends to be higher, and therefore a fortiori electronic commerce tends to fall below it. The White Paper discusses two issues in this regard. The first is whether a computer server located in the United States would create a permanent establishment, given that no employees need to be present.111 The White Paper suggests that the answer is no, and that the computer server may qualify under the exception to permanent establishment for "the use of facilities solely for the purpose of storage, display, or delivery of goods or merchandise."112

Second, a permanent establishment (or a U.S. trade or business) can arise by imputation from the activities of dependent agents, that is, agents with the authority to enter into contracts that bind the principal. ${ }^{113}$ The White Paper suggests that in the typical situation in which an electronic merchant merely utilizes U.S. telecommunications equipment and Internet access providers to enable customers to access its Web site and place orders, no permanent establishment would be created because there is no agency relationship, or at the most an independent agency. ${ }^{114}$

As far as it goes, this analysis seems accurate, even if some of the details may require a considerable stretching of the commonly accepted definitions (a computer server may not be just a storage facility, especially if it also processes credit card information). But this leads to the inevitable conclusion that, consistent with the general thrust of the White Paper, most electronic commerce would not be subject to source-based taxation because it would fall beneath the ju-

109 Id. $\$ 7.2 .3 .1$, at 22 .

$110 \mathrm{Id}$.

111 Id. $\S 7.2 .4$, at $22-23$.

112 Id. \$ 7.2.4, at 23; U.S. Model Treaty, note 73, 1 Tax Treaties (CCH) I 214; OECD Model Treaty, note 99, art. 5, I 4(a), 1 Tax Treaties (CCH) \& 191.

113 See Treasury White Paper, note 2, § 7.2.5, at 23; U.S. Model Treaty, note 73, art. 5 , II 5 .

114 Treasury White Paper, note 2, \$ 7.2.5, at 23; U.S. Model Treaty, note 73, art. 5, 16 ; OECD Model Treaty, note 99, art. 5, I 6, 1 Tax Treaties (CCH) \ 191. 
risdictional threshold in the Demand Jurisdiction, and production can take place in tax havens. ${ }^{115}$

Such a conclusion is unacceptable because (for the reasons discussed in Section IV) there would likely be no residence-based taxation and therefore electronic commerce would be exempt from any taxation at all, violating the Single Tax Principle. Therefore, it is necessary to step back and re-examine the rationale behind the concepts of permanent establishment and U.S. trade or business as currently defined. ${ }^{116}$

The origin of the permanent establishment concept is the work of the Technical Experts group working for the League of Nations in 1927-1928, and its chief proponent was T.S. Adams, the U.S. representative. ${ }^{117}$ As explained by Adams' assistant, Mitchell Carroll, the U.S. delegation was concerned with protecting the interests of U.S. businesses operating abroad, at a time when the United States was a major net exporter of goods:
After World War I when governments were in dire need of revenue to rebuild their economies, they began to try to tax the earnings of the visiting businessman and the profits of the foreign company on goods sold through him. Canada even tried to tax a United States firm on profits from adver- tising its wares and receiving mail orders from customers in its territory. In the early 1920s, the British Board of Inland Revenue sought to impose liability. . . [on] sales through a local commission agent. . . [e]ven if the nonresident and his British intermediary took pains to conclude the contract abroad. ${ }^{118}$

115 This is particularly true of electronic commerce because production facilities can be widely dispersed, but it is true of other commerce as well. Intel, for example, has all of its production locations outside the United States, located in production tax havens. $<$ www.intel.com/intel/community/sites.htm> (visited Feb. 1, 1999) (Puerto Rico, China, Malaysia, Philippines, Ireland, Israel). It still pays tax, however, in countries in which it sells through permanent establishments.

116 One may argue that in the permanent establishment context, this concern would be less serious because the United States does not enter into treaties with tax havens, and therefore the income that falls under the threshold would be subject to taxation on a residence basis. But this conclusion is far from certain, because being a resident of a treaty country does not automatically subject worldwide income to tax; in fact, countries that exempt foreign source income (such as France) typically apply the exemption to active income earned by foreign branches of their residents. See Code Genéral des Impotts, art. 209 (Fr.). Moreover, if the treaty bargain depended on the Benefits Principle, exempting electronic commerce income from tax may change the result of that bargain significantly (because much more active income would be taxable only on a residence basis).

117 Graetz \& O'Hear, note 46, at 1087-88.

118 Id. (quoting Mitchell B. Carroll, International Tax Law: Benefits for American Investors and Enterprises Abroad, 2 Int'l Law 692, 700 (1968)). 
In response, Adams successfully advocated the permanent establishment threshold, which prevented taxation unless the business was conducted through a branch, factory, agency, warehouse, office, or depot. ${ }^{119}$ Independent agents were explicitly excluded (although affiliated companies, interestingly, were not).120 The purpose of the rule was to prevent business from being taxed in every country in which it was operating unless it exceeded a relatively high threshold.121 Interestingly, the Revenue Act of 1921, written under Adams' influence, allowed the United States to tax a nonresident alien merely for conducting a sale in the United States, and this rule persisted until 1934.122 This suggests that the permanent establishment threshold was not intended to limit the concept of source to production activities (even if defined broadly to include marketing). In fact, the current source rule for royalties (also introduced by Adams) would permit the United States to tax a consumer paying a royalty for a license to consume a product in the United States without any production taking place in the United States at all. ${ }^{123}$

The permanent establishment threshold, as Jeffrey Owens points out, may have represented an acceptable compromise when it was first crafted because it dates back to a period in which physical presence was necessary to conduct significant business operations. ${ }^{124}$ Solicitation through the mail, or through independent agents, was certainly possible, but had obvious drawbacks: no direct negotiation with the company's representative, limited ability to customize orders in the case of mass mailings, and orders took a long time to be fulfilled. As pointed out above, electronic commerce fundamentally changes these limitations. ${ }^{125}$ Interactivity, speed, and electronic payment mean that commerce on a much grander scale can be conducted without any physical presence in the consumer's jurisdiction.

It thus appears that if the goal is to tax the income from electronic commerce in a way that preserves the underlying rationale of the permanent establishment rule and the Benefits Principle, a different type of threshold is required, one that is not linked to physical presence. Such a threshold could be a de minimis amount of sales into the juris-

119 See id. at 1088 n.268.

120 Id. at $1088-89$.

121 See id. at 1088.

122 Id. at 1089; see also Revenue Act of 1921, ch. 136, $\$ 217$ (c), 42 Stat. 227, 244 (amended 1934).

123 IRC \& 861(a)(4).

124 Horner \& Owens, note 1, at 516-18; see also Arvid A. Skaar, Permanent Establishment: Erosion of a Tax Treaty Principle 559 (1991) ("At that time therefore, the requirement of permanence at a certain location was not inconsistent with extensive source-state taxation.").

125 See Section II. 
diction, as suggested by Walter Hellerstein and others in the state tax context. ${ }^{126}$ For example, the rule could be that if a seller in electronic commerce has gross sales of $\$ 1$ million or less from a given tax jurisdiction (adjusted for inflation), it would not be subject to taxation at source. The same rule also could be used to define a U.S. trade or business for electronic commerce purposes (in fact, it would be highly advisable to have a uniform definition of these two terms, as is the norm in many other countries). ${ }^{127}$

The figure chosen should be high enough to exclude most small businesses. The growth of electronic commerce enables many small business to sell internationally, and the burden of compliance with various countries' tax laws could be too much to bear for that kind of business. In addition, the threshold should be high enough to ensure that, in most cases, the income derived from the jurisdiction would exceed the costs of complying with its tax laws.

My recommendation is for a gross sales threshold, rather than a net income threshold, for administrability reasons: A net figure would require that a tax administration know the taxpayer's income from sales into a jurisdiction, which it typically would not have the information to determine, while the gross amount can be determined from the records of other parties (the customers). For the same reason, a threshold based on a percentage of total sales worldwide seems impracticable since it requires knowledge available only to the taxpayer.

A key issue is obviously the determination of what would constitute a sale into a jurisdiction. Fundamentally, the inquiry should be where the goods or services sold are consumed. Since making that determination is difficult, however, some simpler proxy like a billing address can be used. In the income tax context, a billing address may be adequate for most individual customers, since (1) they are unlikely to consume the product elsewhere, and (2) they do not have an incentive to provide a false address because they typically do not bear the tax burden. For business customers, both of these factors may be absent because the billing address may be anywhere (including in particular tax havens), and, in the case of large customers, collusion is a possibility. In that case, however, since the customer is physically present in the taxing jurisdiction, an audit may be able to determine the actual location in which a product was used. Moreover, businesses may have an incentive to locate the destination of goods or services provided to

126 Walter Hellerstein, State Taxation of Electronic Commerce, 52 Tax L. Rev. 425, 497 (1997).

127 Hugh J. Ault, Brian J. Arnold, Guy Gest, Peter Melz, Minoru Nakazato, Albert J. Rädler, J. Mark Ramseyer, John Tiley, Richard J. Vann \& Kess Van Raad, Comparative Income Taxation: A Structural Analysis 432-33 (1997) (citing, as examples, Japan, the Netherlands, Sweden, and Germany). 
them in a high-tax jurisdiction, because that would maximize the value of the deduction they would take for the value of such goods or services in determining their own income tax liability.

In this context, some help actually may be available to tax administrators because of the nature of electronic commerce. The ground rules of the Internet can be modified to permit tracking of sales to take place without unduly infringing on privacy concerns (tax administrators need to know only the amount paid by a consumer, not the content of the goods and services provided). For example, some type of "digital certificate" attesting to the residence of a consumer in a country (and thus enabling tax to be collected by that country) may be required to effect sales in electronic commerce. ${ }^{12 s}$

Another concern with any destination-based source rule in the income tax area is that sellers would use tax haven intermediaries with minimal net income to actually conduct sales into significant markets. That is, KitchenCo (with high income) could sell the kitchen to Linda through an independent reseller located in a tax haven whose margin of profit is minimal, and KitchenCo itself would not be making a sale into the United States. In fact, there are some indications that a lot of electronic commerce actually is conducted by pure distributors, or online malls, which are not affiliated with the producers of the goods they sell. ${ }^{129}$ Therefore, additional rules are needed to prevent the tax from influencing the choice of organizational form (integrated vs. nonintegrated production and sales).

To prevent such abuse, I propose a withholding tax regime for electronic commerce that would have the following rules:

First, a gross withholding tax is imposed on sales (and services) provided through electronic means into the Demand Jurisdiction, at a rate equal to the corporate tax rate in the Demand Jurisdiction..$^{130}$

As explained above, a sale is defined as being into the Demand Jurisdiction if the goods or services are consumed therein, ${ }^{131}$ under rules similar to a destination-based VAT. Thus, the withholding tax can be levied directly on the electronic transaction if the consumer resides in the jurisdiction, as explained above. It is important to point out that this tax can be imposed by the Demand Jurisdiction unilaterally by

128 For such a change in the ground rules, see, for example, the new regulations on registration of IP addresses, which require up-to-date ownership and contact information for domain name registrants. See Improvement of Technical Management of Intemet Names and Addresses, 63 Fed. Reg. 8,826 (1998) (proposed Feb. 20, 1998).

129 See Internet Shopping: The Once and Future Mall, The Economist, Nov. 1, 1997, at 64.

130 Note that this rule applies to all sellers in electronic commerce, so that no discrimination against foreign sellers is involved.

131 See Section I. 
forbidding merchants from selling goods to its residents unless procedures for withholding the tax are in place.

Second, to obtain a refund or reduction of the gross tax, the taxpayer must file a return showing its deductions (including cost of goods sold).

Thus, the function of the gross withholding tax is to force taxpayers to file a return in a jurisdiction where they have no physical presence. ${ }^{132}$ It may be advisable, for the reasons stated above, to allow at this point a full refund of the tax if the total gross sales fall below the expanded threshold. ${ }^{133}$ The remaining rules thus apply only if the threshold is exceeded.

Third, the Demand Jurisdiction disallows deductions to related and unrelated parties that are located in jurisdictions that do not both impose tax at a similar rate to the Demand Jurisdiction and have the same rules for deductibility, unless those parties file a return and pay tax to the Demand Jurisdiction. ${ }^{134}$

This rule is needed because otherwise there would be an incentive for a high-profit taxpayer to sell its goods into the Demand Jurisdiction through an unrelated distributor with a very thin net profit. The result would distort the taxpayer's choice of the degree of integration in its operations. Moreover, it is necessary to impose similar restrictions on deductibility on the jurisdiction of the seller in this transaction, because otherwise it would be possible to avoid the rule by interposing another distributor with thin profits in a jurisdiction with

132 This is similar to the rule for U.S. real estate transactions. See IRC $\$ 1445$.

133 Although this violates the Single Tax Principle if the result is no current tax anywhere, this seems acceptable in the small business context. A seller into a Demand Jurisdiction would only include on its return the income it believes is attributable to sources in the Demand Jurisdiction (that is, marketing income), not the income it attributes to production. Thus, if the jurisdiction in which it produces the goods sold into the Demand Jurisdiction is not a tax haven, both countries will retain the right to tax and the only issue will be the proper division of the tax base between them. This is the same problem that arises under the current "attributable to a permanent establishment" standard. Global profit splits, discussed at Section V.C., may be part of the solution to this problem. If, on the other hand, production takes place in a tax haven, any income attributable to it will be taxable in the Demand Jurisdiction, because any deduction for cost of goods sold will be disallowed.

134 Some bright line definition will have to be provided for what constitutes an acceptable tax rate in the seller's jurisdiction. A low rate (for example, over $10 \%$ ) will minimize double taxation while still eliminating most production tax havens, especially if the rate has to be applied uniformly and not just to foreign investors. Any remaining double taxation will be no more than occurs under the current regime because of, for example, limitations on the foreign tax credit.

In addition, the nondeductibility rule should not apply in situations when the income is otherwise subject to tax in the jurisdiction imposing the rule. For example, if a payment is made from Country $A$ to Country $B$ and the resulting income is regarded by Country $A$ as subject to its tax because it has its source in Country $A$, the nondeductibility rule will not apply even if Country $B$ is a tax haven (that is, the payment should only be taxable by Country A once). 
high tax rates. The effect of the rule should be to force sellers who operate through independent distributors to file returns and pay taxes to the Demand Jurisdiction. Thus, all income that is not taxed by another source jurisdiction is allocated to the Demand Jurisdiction.

This rule is similar to the VAT rule that allows deductions for inputs only for purchases from registered VAT payers. It also reflects some aspects of the current international tax regime, for example, the denial of tax sparing credits, ${ }^{135}$ the anti-treaty-shopping rule, ${ }^{136}$ and most recently the hybrid entity rules. ${ }^{137}$ All of these rules, which the United States has emphasized recently, ${ }^{138}$ reflect the view that the source country should not reduce its tax unless it can be sure that the income is really subject to tax somewhere. This, in turn, is congruent with the Single Tax Principle. ${ }^{139}$

Allocating income tax revenues to the jurisdiction in which consumption takes place may seem strange at first, because income usually is linked with production, not consumption. The question may be asked: If the tax base is allocated to the Demand Jurisdiction, should it not be a consumption, rather than an income, tax? But the issue of which tax base to choose (income or consumption) is different from the question which jurisdiction should get the revenues (production or consumption). It is not illogical to allocate income tax revenues to consumption jurisdictions, just as it is not illogical to allocate an origin-based VAT to the production jurisdiction. Moreover, under the proposed regime, only income that is untaxed in the production jurisdiction, or that does not belong to any jurisdiction, is allocated to the Demand Jurisdiction. Thus, taxation by the Demand Jurisdiction should be viewed primarily as a way of enforcing the Single Tax Principle, because it is less likely to be a tax haven than either residence or production jurisdictions. Major consumer markets are rarely tax havens (the costs of operating such a market are too high).140

135 This has been U.S. treaty policy since 1959. See OECD, Tax Sparing: A Reconsideration 12 (1997).

136 IRC \& 884(e)(1)(B).

137 IRC § 894(c), (d)(2); Temp. Reg. § 1.954-9T.

138 See, e.g., Notice 98-11, 1998-6 I.R.B. 18, withdrawn by Notice 98-35, 1998-27 I.R.B. 35.

139 The Single Tax Principle is congruent with taxing individuals on a source basis when there is no residence-based taxation, especially in the case of active business income. Thus, taxing the Bermuda designer on a source basis is acceptable under the Single Tax and Benefits Principles even though he resides in a low-tax jurisdiction. These rules generally reflect the acceptance of the concept of substitute taxation through denial of deductions or credits when the party on the other side is not subject to tax. See, e.g.. IRC $\S \S 163(j)$, 267(a)(2), 404(a)(5). In this way the income tax is not so different from the VAT.

140 This argument does not justify using income rather than consumption as the tax base; that has to be justified in other ways, and this Article assumes that taxing jurisdictions would like to maintain the income tax. 
Finally, the Demand Jurisdiction refunds the difference between the gross tax and the net tax per the return. The net tax then is credited by the residence jurisdiction of the corporation (if it imposes a corporate tax). ${ }^{141}$ If the residence jurisdiction has an integrated tax regime, credit for the net tax should be allowed at the shareholder level.

While this system appears quite complex, it is fundamentally similar to the rules for a destination-based VAT, except that the tax base is net income and not consumption. These rules seem to operate quite well (with a few notorious exceptions, such as banks) and do not require an elaborate tax treaty network to allocate the tax base among countries. ${ }^{142}$ For the moment, it is important to note that the rules can be adopted unilaterally by the Demand Jurisdiction. Moreover, the information required by the Demand Jurisdiction to implement the rules relates to the tax systems of other countries (which it can find out about), rather than to the specific tax characteristics of the individual taxpayer (which are harder to ascertain). ${ }^{143}$

This regime is congruent with the Benefits Principle because the Demand Jurisdiction is a source of the income (it could not have been earned but for the market). My proposal also permits other jurisdictions in which production activities take place to levy taxes as well, based on the benefits they provide. ${ }^{144}$ Only the income attributable to tax havens is shifted to the Demand Jurisdiction, and this result seems acceptable to prevent violation of the Single Tax Principle.

Were this type of "impermanent establishment" adopted as the international norm for taxing electronic commerce, most electronic commerce by high-volume sellers (as well as traditional mail-order business) could be subjected to taxation at the source by the country in which the consumption of the goods or services takes place. A lot of electronic commerce conducted by smaller businesses would fall under the threshold, just as it currently does under the permanent establishment threshold. If it is not subject to residence-based taxation or taxation at the source by the country in which production takes place, the income will escape tax, which violates the Single Tax Principle. Such an outcome seems an acceptable price to pay to maintain the underlying rationale of the permanent establishment rule, that is,

141 No credit should be given for taxes imposed (through the denial of deductions) to parties that are unaffiliated with the resident taxpayer.

142 This point is elaborated further in Section V.C.

143 Many countries have, for example, controlled foreign corporation regimes that hinge on whether the other country imposes a sufficient tax rate; even sub-country tax variations are taken into considerations, for example, by Australia. See Ault et al., note 127, at 419 . 22.

144 I discuss how to divide the income among source jurisdictions when affiliated entities are involved in Section V.C. 
to prevent business from being subject to taxation by every jurisdiction in which it operates, given the cost of compliance.

As opposed to the permanent establishment rule, a numerical threshold seems better suited to prevent the imposition of taxes in those cases in which the burden of compliance exceeds the amount of tax that can be collected. At the same time, a numerical threshold would prevent most electronic commerce from escaping tax altogether, as it might under current permanent establishment and U.S. trade or business rules, a result that would violate both the Single Tax and Benefits Principles.

\section{B. Royalties, Services, and Sales}

The problem of classifying the income derived from electronic commerce into categories is crucial because, under current law, the source of income is determined separately by category. ${ }^{145}$ Thus, income from sales generally is sourced to the residence of the seller, ${ }^{146}$ royalty income is sourced to where the intangible giving rise to the income is used, ${ }^{147}$ and income from services is sourced where the services are performed.148

As the White Paper points out, electronic commerce requires the examination of those principles because it blurs the lines among the categories. ${ }^{149}$ For example, a purchase of a hard copy of a book would constitute a sale, but the downloading of a copy of that book from the Internet may give rise to royalty income because the customer has the ability to make an unlimited number of perfect copies of the book and sell them, so that the initial payment represents compensation for the privilege of using a copyright. ${ }^{150}$ Moreover, if the customer also acquired the right to have the information contained in the book updated automatically via the Internet, then perhaps some of the payment constitutes income from performing services.

The White Paper suggests that the new proposed regulations on classifying income from transactions in software "may establish a framework applicable to any type of digitized information, at least to the extent it is protectable by copyright." 151 These regulations build on copyright law and treat transactions in software as involving either: (1) a transfer of copyright rights, (2) a transfer of copies of the copy-

\footnotetext{
145 IRC $\$ \S 861-865$.

146 IRC § 865(a).

147 IRC $\$ 861(a)(4)$.

148 IRC \& 861(a)(3).

149 Treasury White Paper, note $2, \S 7.3 .2$, at 23.

150 Id.

151 Id. § 7.3.3, at 25.
} 
righted program, or copyrighted articles, (3) the provision of services, and (4) the provision of knowhow. ${ }^{152}$ A transaction is treated as the transfer of a copyright right, rather than of a copyrighted article, only if the transferee obtains the right to make copies for public distribution, prepare derivative programs, make a public performance of the program, or publicly display the program. ${ }^{153}$ Otherwise, the transaction is treated as the transfer of a copyrighted article. ${ }^{154}$

A transfer of copyright rights (as defined above) results in sales income if all substantial rights in the copyright are transferred; otherwise, it results in royalty income. ${ }^{155} \mathrm{~A}$ transfer of a copyrighted article is a sale or exchange if all the benefits and burdens of ownership have been transferred; otherwise, it is a lease resulting in rental income. ${ }^{156}$ The provision of services results in services income. ${ }^{157}$

The regulations depart from copyright law in one important way: Most software transactions are characterized as licenses for copyright law purposes to prevent the transferee from making copies of the program for others. The proposed regulations treat this transaction as a sale for tax purposes, however, even if the transferee may (under a "site license") make copies of the program for internal use. Only if the transferee obtains the right to distribute copies to the general public is the transaction treated as a license giving rise to royalty income (as long as not all the rights in the copyright have been transferred). ${ }^{158}$ This result is congruent with the generally pro-residence and antisource bias of the White Paper, because the recharacterization of licenses as sales shifts the right to tax from where the intangible is used (the source country) to where the seller resides (the residence country). But it leads to lines that are very difficult to draw. For example, if a company that manufactures computers loads a copy of a program on the hard drive from a single disk received from the creator of the program, that is treated as a license and the payment to the creator is a royalty. If a separate physical disk is received and installed on each computer that is sold, that is treated as a sale of the program..$^{159}$

The proposed regulations would treat a transaction as not involving income from services unless the services component is substantial, such as when the customer bears all the risk of loss for the creation of

\footnotetext{
152 Prop. Reg. § 1.861-18(b)(1).

153 Prop. Reg. § 1.861-18(c)(1), (2).

154 Prop. Reg. \$ 1.861-18(c).

155 Prop. Reg. \& 1.861-18(f)(1).

156 Prop. Reg. § 1.861-18(f)(2).

157 Prop. Reg. § 1.861-18(b)(1)(iii).

158 Prop. Reg. $\S 1.861-18(\mathfrak{f})(1)$.

159 Prop. Reg. $\S 1.861-18($ h)(Exs. 7, 8).
} 
a computer program and owns all the copyright rights. ${ }^{160}$ Merely updating a sold program will not give rise to services income, but it is not clear where precisely the boundary between de minimis and substantial services lies. ${ }^{161}$ The White Paper cites the following example of a person accessing an encyclopedia on-line. ${ }^{162}$ If the encyclopedia had been purchased in hard cover form, the transaction would have been treated as a sale even though most of the value results from services. Similarly, the sale of a CD-ROM containing the encyclopedia may result in sales income. If, however, the on-line encyclopedia is accessed frequently for a separate payment each time, the White Paper suggests this may result in treating the transaction as the provision of services. On the other hand, where there is only one up-front payment, the transaction may be a sale while the CD-ROM transaction may be treated as services if there are monthly updates for a fixed upfront fee. It is hard to establish a precise line between sales and services in this case.

The provision of services in electronic commerce poses a special problem because the source rule for services was developed when the provision and consumption of services generally took place in the same location (although lawyers, for example, were always able to provide services at a distance, and barbers are still unable to provide most services electronically). For many types of services, it is now relatively easier for the provision and consumption of the service to take place in separate locations. Physicians, for example, may be able to diagnose patients through video images and provide treatment recommendations electronically. The White Paper, recognizing this, suggests that it is another reason to increase the role of residence-based taxation. ${ }^{163}$ But in this case as well, the fact that income from services may have more than one source does not mean that it cannot be taxed at the source, especially if residence-based taxation is unlikely to occur.

None of these problems, of course, is really new. The tax law has struggled for decades to distinguish among royalties, services, and sales: Is the transfer of copyright rights for a lump sum a sale or a royalty? ${ }^{164}$ Does an artist who sells his own painting earn sales or

160 Prop. Reg. $\$ 1.861$ (h)(Ex. 15).

161 Prop. Reg. \$ 1.861-18(h)(Ex. 12).

162 Treasury White Paper, note 2, § 7.3.4, at 26.

163 Id. \$ 7.4.2, at 27.

164 See Commissioner v. Wodehouse, 337 U.S. 369 (1949) (lump sum paid for the transfer of copyrights constitutes rents or royalties rather than proceeds from a sale). 
services income? ${ }^{165}$ Does a musician performing in the United States for a percentage of the proceeds from the sale of records earn services or royalties income? ${ }^{166}$ How about an inventor working for a pharmaceutical company that pays him a percentage from the sale of his invention?167 But the rise of electronic commerce does appear to increase the frequency in which these problems are likely to arise. Consider the Linda Jones-KitchenCo example. ${ }^{168}$ Is KitchenCo earning income from sales, because it is selling a kitchen? Or for services, because it is providing design services? Or royalty or rental income, because it is providing a computer program that Ms. Jones can use to change the design, but must return to KitchenCo once the kitchen is installed? The most plausible answer under the software regulations is that the transaction involves all three types of income. But as long as the tax law sources each type of income differently, it would be crucial to break up the payment to KitchenCo into its component parts, which may be very difficult to do.

A more acceptable answer may be to step back and ask whether having separate source rules for each category of income makes sense for electronic commerce. Fundamentally, the categories for which $\S 861$ and the following sections of the Code provide source rules can be divided into two general types. On the one hand, there is passive investment income, such as portfolio dividends, portfolio interest, and capital gains from the sale of investments. ${ }^{169}$ Under the Benefits Principle, these types of income should not be subject to source-based taxation at all, except as a backstop in those cases that residence-based taxation is not imposed. Thus, as suggested elsewhere, the source rule for them can be formalistic (such as the residence of the payor) and whether a withholding tax is imposed on them can depend on whether the income underlying them has been taxed once (which suggests taxing interest because it is deductible to the payor, but not dividends or capital gains). ${ }^{170}$

165 See Tobey v. Commissioner, 60 T.C. 227 (1973) (paintings were the efforts of taxpayer's personal efforts and thus income derived from their sales was "earned income" within $\S 911(\mathrm{a})(1))$.

166 See Boulez v. Commissioner, 83 T.C. 584 (1984) (under the effective income tax treaty between the Federal Republic of Germany and the United States, payments to taxpayer for performing recordings of orchestral works were not "royalties" exempt from U.S. tax, but were compensation for personal services, and taxable by the United States).

167 See Karrer v. United States, 152 F.Supp. 66 (Ct. Cls. 1957) (payments from domestic corporation to nonresident alien in the amount of a percentage of proceeds of sale of invented processes constituted compensation for alien's services rendered in foreign country and were not subject to U.S. tax).

168 See Section I.

169 IRC $\S \S 861(a)(1),(2), 865(a)$.

170 Reuven S. Avi-Yonah, Virtual Taxation: Source-Based Taxation in the Age of Derivatives, 1996 Nat'l Tax Ass'n Proc. 269, 272 (1997). 
The other categories, such as royalties, services, and capital gains from sales of inventory property are active business income, and therefore under the Benefits Principle should be subject to taxation primarily at source. It therefore would appear appropriate to apply to them, for electronic commerce purposes, a single sourcing rule, that is, the rule suggested above: The source of the income is the location of consumption. This does not mean that this is the only source of the income; in fact, the income from active business typically has many sources, including the location of production. I discuss how to allocate the income among all those sources in the next Section. Because the location of production is more likely to be in a tax haven than the location of consumption (for the reasons discussed above), as a preliminary matter, the market jurisdiction should assert its right to tax the income, before adjusting to the claims of other countries.

My proposal is therefore to sidestep the classification issue by subjecting services, royalties, rents, and sales in electronic commerce to the same sourcing rule, based on where consumption of the goods or services provided takes place. In addition, because these types of income are derived from active business operations, they generally should not be subject to taxation on a gross basis. Thus, unless these types of income from electronic commerce cross the proposed threshold for taxation of business profits (that is, $\$ 1$ million in gross income), they should not be taxed by the source country; once the threshold is crossed for a taxable year, the provider of goods and services would be required to file a return and be taxed on a net basis.

\section{Transfer Pricing}

The proposal contained in Section V.A. is adequate to source income among the various source countries when taxpayers are unaffiliated with each other. Under this proposal, each source jurisdiction that wishes to do so would tax the income earned by taxpayers within it, as defined by market transactions. Income that is untaxed (in accordance with the Single Tax Principle) would be allocated to the Demand Jurisdiction. But what should be done when taxpayers are affiliated with each other, so that there are no market transactions to allocate income among its various sources?

This is the fundamental problem underlying the transfer pricing issue. ${ }^{171}$ If one treats a multinational enterprise as a single, integrated economic entity earning income from many sources, how can one ap-

171 For an extensive discussion, see Reuven S. Avi-Yonah, The Rise and Fall of Arm's Length: A Study in the Evolution of U.S. International Taxation, 15 Va. Tax Rev. 89 (1995) [hereinafter Rise and Fall]. 
portion that income among many taxing jurisdictions? How to assure (in accordance with the Single Tax Principle) that all the income of the multinational is taxed once, rather than not taxed at all or subject to multiple taxation?

Under the traditional arm's length standard, the answers to these questions depended on treating the portion of the multinational in each jurisdiction that had the power to tax it under the permanent establishment threshold as if it were dealing with other parts of the multinational at arm's length. ${ }^{172}$ The establishment of arm's length prices in turn depended on finding comparable transactions among unrelated parties that could be used to establish the correct market price. ${ }^{173}$

In many cases, however, such comparables cannot be found, primarily because of the existence of intangibles that are proprietary to the multinational. ${ }^{174}$ This has led to the decline and fall of this traditional arm's length regime, which has been described extensively elsewhere, ${ }^{175}$ and to the widespread adoption of the profit split method, which is included both in the U.S. transfer pricing regulations ${ }^{176}$ and in the OECD guidelines. ${ }^{177}$ The key to profit split is that it does not depend on comparables; instead, it is based on a functional analysis of each part of the multinational, resulting in the assignment to each function of the profit appropriate to it under a market-based return. ${ }^{178}$ Any residual profit then is assigned, according to the U.S. rule, to the location where the costs of developing the intangible assets that are presumed to give rise to the residual were incurred. ${ }^{179}$ This is a proU.S. rule because so many high value intangibles are developed here, and the OECD guidelines are silent on the topic of how to allocate the residual, beyond invoking the arm's length concept, which is usually inapplicable since comparables cannot be found. ${ }^{180}$

The other principal difference between the U.S. transfer pricing rules and the OECD guidelines is that the latter insist that profit splits must be applied on a separate transaction basis (that is, to the profit from a given transaction), while the former appear to leave open the possibility of applying profit split to the global profits from an entire

172 Id. at $90-91$.

173 Id.

174 Id. at $112-28$.

175 See Avi-Yonah, Rise and Fall, note 171.

176 Reg. $§ 1.482-3($ a) $-6(c)$.

177 OECD, Transfer Pricing Guidelines for Multinational Enterprises and Tax Administrators (1995), reprinted in 9 Tax Notes Int'l 155, 179-80 (July 18, 1994) [hereinafter OECD Guidelines].

178 Id.

179 Reg. § 1.482-6(c)(3)(i)(B).

180 OECD Guidelines, note 177. 
line of business. ${ }^{181}$ The U.S. approach is thus closer to global formulary apportionment as practiced by the U.S. states. In fact, in the context of global trading, the United States, the United Kingdom, and Japan have agreed on principles of allocation that rely on profit split formulas, and these principles recently have been reflected in U.S. regulations $\mathrm{S}^{182}$ and in guidelines issued by the OECD. ${ }^{183}$

This last example brings us back to electronic commerce, because global trading is a prime example of electronic commerce. As Jeffrey Owens, the head of the OECD fiscal affairs division, has pointed out, the rise of electronic commerce poses a serious challenge to the application of the OECD transfer pricing guidelines. ${ }^{184}$ The reason can be seen if one ponders KitchenCo's operations. First, it is hard to apply functional analysis to each portion of KitchenCo, because any given function may be performed in several places. For example, the design of the kitchen is performed in Australia (where the software was written), Argentina (location of the design computer), Bermuda (location of the designer), and the United States (where Linda participated in the design process). The manufacturing is performed in Malaysia (location of the factory), Germany (source of the appliances), Italy (location of the consultants), and the United States (where the kitchen was installed and modified). Functional analysis would require breaking up these traditional functions into ever smaller sub-functions, and as Mr. Owens points out, this process would make it exceedingly difficult to find a market return for each sub-function. ${ }^{185}$

Second, the speed with which transactions take place over the Internet is likely to sharply increase the volume of transactions. This would make it more burdensome to apply separate transactional pricing, as envisaged by the OECD guidelines.

Third, the development of corporate intranets is likely to increase the volume of business multinationals conduct internally, as opposed to transactions with outside parties. In the KitchenCo example, all the transactions could take place on an intranet except for the contact with Linda Jones. This would increase the degree to which multinationals operate as single, unified entities, and make it more difficult to find comparable transactions with outside parties. ${ }^{186}$

All of these developments suggest that the proper approach to taxing electronic commerce when affiliated entities are involved is the

181 Prop. Reg. \& 1.482-8.

182 Id. at 180-84; Reg. $\$ 1.482-6$ (c).

183 John Neighbour, OECD, The Taxation of Global Trading of Financial Instruments, 16 Tax Notes Int'l 1269 (Apr. 20, 1998).

184 Horner \& Owens, note 1 , at 520-21.

185 Id. at 521.

186 Id. at 520. 
one adopted in the global trading area, namely some version of global profit split. If it were possible to agree on a formula to apportion a multinational's profit from electronic commerce among the various source countries, the problem of avoiding both under- and overtaxation would be much closer to resolution. (In accordance with the Benefits Principle, taxation of such active business income is to be shared among source jurisdictions, with no residence-based taxation).

The path towards achieving consensus on this type of issue is the one pursued in the global trading context: negotiation of an advance pricing agreement among the tax authorities involved that applies to specific types of operations by specific taxpayers. The obstacles to such a procedure are (1) the lack of an appropriate forum, given that the agreement must encompass many countries (and not just three, as in the global trading example) and (2) the sheer number of agreements that would be required. The first obstacle perhaps can be overcome by the establishment of a multilateral forum. The second obstacle is mitigated by the fact that the number of truly large multinationals is limited: Currently, the top 300 multinationals own about one-quarter of the world's productive assets, ${ }^{187}$ and one-third of world trade takes place among their affiliates. ${ }^{188}$ If it were possible to reach agreements with those multinationals, a large percentage of the problem would be solved.

For smaller companies, and for multinationals that do not enter into an advance pricing agreement, a different approach is needed to preserve the Single Tax and Benefits Principles. As an initial step, the Demand Jurisdiction will impose a gross withholding tax on payments for sales into its jurisdiction. ${ }^{189}$ The next step requires the seller to file a return showing deductions, which are allowed or disallowed based on whether the provider of the deductible good or service pays tax at an adequate rate.

This rule is adequate for unrelated providers. In the case of payments to affiliated providers of goods or services, such payments also would not be deductible if they are not taxed to the provider (for example, because it resides or has operations in a low-tax jurisdiction). Thus, all income that is untaxed because the jurisdiction in which it is earned does not impose an adequate tax will be taxed in the Demand Jurisdiction. This result is consistent with both the Single Tax and Benefits Principles (all active business income is subject to tax by a source jurisdiction).

187 Bill Emmott, Multinationals Back in Fashion, Everybody's Favorite Monster: A Survey of Multinationals, Economist, Mar. 27, 1993, at 6.

188 UN, Conference on Trade and Development, World Investment Report 1 (1996).

189 See Section V.A. 
In the case of payments to providers who are subject to tax by another source jurisdiction, a global profit split analysis should be applied. Thus, a functional analysis could be performed to allocate market-based returns to the routine functions performed in both jurisdictions (for example, production and marketing functions). A functional analysis of routine functions should be possible even where they are widely dispersed. As explained above, however, a large residual is likely to remain, resulting from the rents obtainable by the multinational by virtue of its being a multinational. Any such residual should be taxable in the Demand Jurisdiction, that is, no deduction would be allowed for the portion of the payment that represented the residual profit.

Under this proposal, both income that is untaxed because of tax holidays and similar incentives, and income that does not belong to any jurisdiction (that is, residual profits), would be allocated to the Demand Jurisdiction. The rationale for this allocation is two-fold. First, once Demand Jurisdictions were allowed to impose the withholding tax, they would have the "first bite at the apple" and therefore would be likely to prevail in any contest about who gets the revenue. This reasoning is similar to the practical rationale for preferring source over residence jurisdiction for active business income.

Second, a rule that favors destination-based taxation is the most likely candidate to gain international acceptance, either unilaterally or through a multilateral forum. The reason is the one given by Charles McLure for preferring destination-based taxes in general: All countries tend to prefer to tax imports and exempt exports. ${ }^{190}$ Taxation by the Demand Jurisdiction has that effect, and therefore is likely to be accepted by countries in which production takes place, especially if they are also significant importers. ${ }^{191}$ As emphasized by McLure, destination-based taxes can be accepted even without a multilateral forum, as evidenced by the destination-based VAT. ${ }^{192}$

To sum up, consider the KitchenCo example to illustrate how the various rules proposed in this Article for taxing electronic commerce might work in practice. Suppose that Linda Jones pays KitchenCo $\$ 50,000$ for the kitchen. KitchenCo, in turn, has the following costs:

190 Charles E. McLure, Jr., Substituting Consumption-Based Direct Taxation for Income Taxes as the International Norm, 45 Nat'l Tax J. 145, 146-47 (1992) [hereinafter International Norm].

191 Arguably, this rule violates the GATT prohibition on export subsidies for direct taxes. Stephen E. Shay \& Victoria P. Summers, Selected International Aspects of Fundamental Tax Reform, 51 U. Miami L. Rev. 1029, 1048 (1997). It is not clear, however, that the GATT rule, which relies on an outmoded distinction between direct and indirect taxes, makes sense. Id. at 1049-50.

192 McLure, International Norm, note 190, at 151. 
Payment to Bermuda designer

Royalty for Australian software

Depreciation of Argentina computer

Payment to Italian artisans

Payment to Malaysian workers

Materials from Malaysian suppliers

Appliances from German suppliers

Assume that the suppliers in Australia, Italy, and Germany are subject to effective average tax rates comparable to the corporate rate in the United States, but that Malaysia only taxes the employees and not the suppliers, and Bermuda does not tax the designer. In that case, KitchenCo would be able to deduct only $\$ 22,000$, and would have taxable income in the United States of $\$ 28,000$, which in effect would represent a tax on the designer in Bermuda and the suppliers in Malaysia as well as on its own profit.

The same result would apply if the suppliers in Malaysia and Germany were affiliates of KitchenCo. In that case, the payment to the Malaysian supplier would not be deductible. The payment to Germany would be deductible to the extent that it represented a marketbased normal return for the functions performed by that supplier, but not to the extent of any residual resulting, for example, from special know-how intrinsic to KitchenCo's operations.

\section{Conclusion: A Comparative Perspective}

The rise of electronic commerce poses problems for both main types of tax employed by governments today, namely income taxes and consumption taxes. The categories used by these taxes were developed before electronic commerce became a reality, and therefore do not take the possibilities for transacting business at a distance that electronic commerce offers into account. Because of this mismatch, the rise of electronic commerce threatens to severely undermine the traditional income tax bases, and some scholars have suggested that an entirely new type of tax, the "bit" tax, is needed to cope with electronic commerce. ${ }^{193}$

This Section compares the treatment of electronic commerce under the international tax regime, which has been the focus of the Article, with three other types of tax: the U.S. state corporate income tax, the U.S. state retail sales tax, and the value added tax. The goal is to compare the treatment of electronic commerce under these various taxes and assess the seriousness of the problems it poses for each. By

193 See Cordell, et al., note 8; Soete \& Kamp, note 8, at 21-22. 
doing so, one can decide whether a new type of tax is the only solution, or whether the traditional taxes can be modified to apply to electronic commerce as well as to traditional commerce.

\section{A. Electronic Commerce and U.S. State Income Taxes}

This Article has focused on the three major problems posed by electronic commerce to the international tax regime: the reliance on physical presence (permanent establishment) for jurisdiction to tax, the difficulty of establishing the source of income, and the difficulty of transfer pricing based on comparables.

Given these problems of the international tax regime, it is instructive to compare how electronic commerce fares under a different type of income tax regime, the one used by the U.S. states. This regime has not received much attention in the electronic commerce context in comparison with U.S. state retail sales taxes, ${ }^{194}$ but it offers some useful points of contrast with the international tax regime issues outlined above.

The U.S. states do not have a permanent establishment concept applicable in the income tax area. The physical nexus requirement, which has attracted a lot of attention in the retail sales tax area, probably does not apply in the income tax area, and under case law, intangible assets may be sufficient to constitute nexus. ${ }^{195}$ The only applicable limitation is contained in a 1959 law limiting the right of states to tax sellers whose only activity in a state is "mere solicitation," but its relevance to electronic commerce is unclear. ${ }^{196}$ In particular, the law may not apply to intangible goods or to foreign sellers, and thus may not cover most electronic commerce. ${ }^{197}$

Thus, U.S. states generally are not extremely worried that electronic commerce will erode their income tax base. States apply their income taxes using a formulary apportionment of income based on payroll, tangible assets, and sales within their jurisdiction. ${ }^{19 s}$ Once nexus is established, an out-of-state seller with no payroll or assets in a state is

194 See Hellerstein, note 126, at 476-80, 497-503; Charles McLure Jr., Taxation Of Electronic Commerce: Economic Objectives, Technological Constraints, and Tax Law, 52 Tax L. Rev. 269, 335-49, 416 (1997).

195 See Geoffrey, Inc. v. S.C. Tax Comm'n, 437 S.E.2d 13 (S.C. 1993) (holding that a corporation was liable for income tax based on the presence of intangibles (a license and an account receivable)).

195 Pub. L. No. 86-272, § 101(c), 73 Stat. 555 (1959), 15 U.S.C. § 381(c) (1997); see also Wisconsin Dept. of Revenue v. William Wrigley, Jr., Co., 505 U.S. 214 (1992) (discussing what solicitation means and what activities amount to solicitation).

197 This is the position taken by California in Appeal of Dresser Indus., $1982 \mathrm{Cal}$. Tax LEXIS 222 (St. Bd. of Equalization June 29, 1982), reh'g denied, 1983 Cal. Tax LEXIS 40 (St. Bd. of Equalization, Oct. 26, 1983).

198 See Uniform Division of Income for Tax Purposes Act § 9, 7A U.L.A. 331 (1985). 
subject to tax based on the sales factor. Recently states have tended to emphasize the sales factor more, giving it double or even exclusive weight, to shift the tax more to importers and less to exporters. ${ }^{199}$ Vendors engaged in electronic commerce thus may find themselves exposed to state income tax liabilities based on where their customers reside.

In addition, the use of a destination-based regime and formulary apportionment generally means that states do not need to worry about categorizing income for purposes of determining its source. All the income of a corporate taxpayer from its active business operations (investment income is a different, and complicated, issue) is allocated (that is, sourced) based on the formula, so that the distinction among sales, services, and royalties loses its importance. In a formula that gives double weight to sales, this is equivalent to splitting the entire income among the residence and source jurisdictions on a 50/50 basis.

Finally, using formulary apportionment solves the transfer pricing issue. The use of formulas by the U.S. states has been extremely controversial ${ }^{200}$ and the formula they use is too simple for the international context. As suggested above, however, given the limited number of taxpayers involved in major transfer pricing issues, it perhaps may not be too far fetched to argue that such tailored formulas can be negotiated with most of them. Thus, in this area as well, the international tax regime can benefit from the methods used by the U.S. states.

\section{B. Electronic Commerce and U.S. State Retail Sales Taxes}

By way of contrast to the U.S. state income tax treatment of electronic commerce, which is relatively unproblematic, the state tax treatment of such commerce for consumption tax purposes suffers from grave deficiencies. These deficiencies arise because the state sales and use taxes date from an era in which commerce consisted mostly of sales of tangible, physical products requiring a tangible, physical presence in the jurisdiction into which they are sold.

The most obvious problem area is nexus. Under the Supreme Court's decision in Quill v. North Dakota, the states are prohibited from requiring vendors to collect compensating use taxes on sales to

199 More than one-haif of the U.S. states have adopted a modified three-factor formula, assigning greater weight to the sales factor than the property or payroll factors. See 1 Karen J. Boucher \& John C. Healy, 1998 Multistate Corporate Tax Guide 490, 562-67 (1998) [hereinafter Tax Guide I]. The majority of these states double-weight the sales factor. Id. at 490 . Three states, Iowa, Nebraska, and Texas, have adopted a general singlefactor apportionment formula that includes only the sales factor. Id.

200 Barclays Bank PLC v. Franchise Tax Bd., 512 U.S. 298, 324 n.22 (1994) (discussing international opposition to California's use of formulary apportionment). 
their residents unless the vendors are physically present in the state.201 Since use taxes cannot in most cases be collected from consumers without vendor cooperation, this amounts to an exemption from tax for electronic commerce sales. Thus, the states face the prospect of losing much of their sales tax base, which already has been eroded by mail order catalogue sales, if nothing is done to remedy the situation.

Whether something can be done depends on Congress, which so far has been reluctant to act (in fact, it has imposed a moratorium on state taxation of electronic commerce). ${ }^{202}$ Proposed legislation would substitute a de minimis threshold of sales for the physical presence requirement. ${ }^{203}$

There are two other problem areas in the U.S. state retail sales tax area, however, that dwarf the nexus issue, although that has received most of the attention so far. First, the retail sales tax generally does not apply to services, because it was adopted at a time that services were a small portion of economic activity (some states tax specific services). ${ }^{204}$ Today, services in the global economy are growing much faster than goods, and they form the larger part of electronic commerce. Even if the nexus issue is solved, unless services can be taxed, most of electronic commerce will escape the retail sales tax net.

Even more problematic is the cascading nature of the tax. In principle, consumption taxes are supposed to apply only to retail sales to consumers, and not to sales to businesses. In practice, the only exception from the application of the tax to goods is where they are either resold or physically incorporated in other goods that are resold. Thus, a huge number of business-to-business transactions end up being taxed, and the tax is included in the price of the final good, so that the result is a tax upon a tax. Interestingly, services provided to business, including electronic commerce services, thus end up being taxed when their cost is incorporated into the price of the final good.

The obvious solution is for states to exclude sales to businesses, and pay for the revenue loss by expanding the tax base to cover services. This requires cooperation among the states, which so far, has not been forthcoming.

201504 U.S. 298 (1992). For an extensive discussion, see Hellerstein, note 124, at 437-41.

202 Internet Tax Freedom Act, Pub. L. No. 105-277, § 1101, 112 Stat. 2681 (1998).

203 Id.; Hellerstein, note 126, at 497.

204 States recently have been enacting statutes specifically imposing tax on certain services not previously taxed. II Karen J. Boucher \& John C. Healy, 1998 Multistate Corporate Tax Guide 89 (1998) [hereinafter Tax Guide II]. A number of states have attempted to impose sales tax on services provided on the Internet. Id. Some states tax all services. Id. at 100-05. For example, New Mexico taxes all services. N.M. Stat. Ann. \$\$ 7-9-4, 7-9-7 (Michie 1998). 


\section{Electronic Commerce and the VAT}

Once again, it is instructive to compare the treatment of these type of issues under a different type of consumption tax, the VAT (which can be either an invoice-credit or subtraction type VAT). ${ }^{205}$ First, the nexus problem does not arise. The VAT rule for goods is the destination principle (similar to that used by the U.S. states in the retail sales tax area), so that vendors are taxed when they import goods into a destination (and pass the tax on to their consumers). ${ }^{206}$ No physical presence in the destination country is required.207 Interestingly, this means that countries give up on taxing value added within their borders when they zero rate exports, ${ }^{208}$ and this rule is universally applied without the need for tax treaties, just as the U.S. states all apply the destination principle to the sales factor without needing treaties. ${ }^{209}$

The situation for services is more complicated. Services are included in the VAT tax base, which is superior to the U.S. state retail sales tax in this regard.210 The liability to tax is determined based on the place of supply, which traditionally has been defined (for example, in the European Union's Sixth Directive) ${ }^{211}$ as the residence of the supplier. ${ }^{212}$ This rule is problematic for electronic commerce because the supplier can be resident in a country that is a tax haven from a VAT perspective (for example, the United States). Recently, however, there has been a growing tendency to use a so-called "reverse charge" rule, in which the place of supply is the location of the consumer, at least for business-to-business sales. ${ }^{213}$ This rule recently was adopted by the EU for telecommunication services, and it applies to entertainment as well. ${ }^{214}$ Thus, it appears likely that electronic commerce can be taxed for VAT purposes under a reverse charge regime, similar to the destination rule applicable to goods.

Finally, the VAT avoids the cascading problem faced by the U.S. state retail sales tax by in most cases allowing an input credit for taxes paid by suppliers to registered VAT taxpayers, or (in a subtraction VAT) allowing the supplies to be deducted from taxable outputs. This rule allows for near perfect matching: Deductions are permitted only

2053 Treasury Dep't, Tax Reform for Fairness, Simplicity, and Economic Growth: Value Added Tax 7-8 (1984) [hereinafter Treasury I].

206 Id. at $11-12$.

207 Id. at 12.

203 Id. at 41.

209 Id. at $26-27,46$.

210 Id. at $31,47-48$.

211 Council Directive 82/891/EEC, 1982 O.J. (L378) 47.

212 Treasury I, note 205, at 45-46.

213 Adrian Ogley, Principles of Value Added Tax: A European Perspective 80-82 (1998).

214 Id. at 134. 
when the party on the other side has paid the tax. Matching makes tax avoidance much harder and also enables the tax to be collected on a substitute basis (that is, when the seller cannot be taxed, the tax is collected from the buyer by not allowing a credit or deduction). The absence of such matching in the income tax means that the tax must be collected from all taxpayers separately with (generally) no substitution, which leads to huge administrative difficulties.

\section{The Impact of Electronic Commerce: Substitution or Borrowing?}

Does the rise of electronic commerce require abandoning the traditional taxes and substituting new taxes, such as the "bit" tax? The answer is no: The traditional taxes can be applied to electronic commerce. In fact, some of them, like the VAT or the U.S. state income tax, are quite suitable for adaptation to an electronic commerce environment.

The answer to the challenge of electronic commerce is not to substitute one tax for another; the traditional taxes have strong normative foundations and are based on a well-developed international consensus, which it would be unfortunate to lose ("an old tax is a good tax"). The answer, instead, is creative borrowing of the methods of one tax regime into another, in the ways suggested in this Article. Specifically, the suggestions made above for modifying the international tax regime for electronic commerce are all based on incorporating elements from the U.S. state income tax: (1) abandon the permanent establishment rule and replace it with a threshold of a de minimis amount of sales into a jurisdiction; (2) abolish the distinction among sales, services, and royalties and include all of them in the threshold amount; and (3) deal with transfer pricing by adopting global profit splits that take into account the interests of all source jurisdictions. As suggested above, the income tax can also benefit from some of the methods of the VAT, like disallowing deductions for inputs (including cost of goods sold) unless the party of the other side can demonstrate that it is subject to tax (that is, a matching requirement). Similarly, the U.S. state retail sales tax does not have to be replaced by a VAT, but it can borrow from it the inclusion of services, the avoidance of cascading, and the lack of a physical presence requirement for nexus.

Whether any of this is possible remains to be seen, and much of it requires multilateral approaches. But it would be unfortunate if a premature decision was taken to abandon the traditional taxes for a bit tax, or even abandon the income tax for a consumption tax, before undertaking a serious study of the possibility of meeting the challenge of electronic commerce along the lines outlined above. 
